\title{
The Identity of Corporate Ownership in the Industrialized World: Size, industry and country effects
}

Eelke de Jong* and Radislav Semenov, Department of Economics, Radboud University Nijmegen, The Netherlands

\begin{abstract}
This paper provides a new and unique dataset, which contains information about ownership, size and industry for 6668 companies in 24 industrial countries. The shares of larger firms are more often widely held or controlled by listed non-financial companies (in particular, widely held companies) and governments. Smaller firms are more likely to have a family, an unlisted company, an institutional investor, or a bank as the dominant shareholder. Differences between countries can be large: in Italy families hold large firms, whereas in Portugal they only own small firms. Utilities are often owned by a government agency. Except for aircraft, the high-technology industries are often widely held companies.
\end{abstract}

This version: February 2006

Keywords: corporate ownership, cross-country.

JEL codes: G32, G38

* Corresponding author. Department of Economics, Radboud University Nijmegen, P.O. Box 9108, 6500 HK Nijmegen, The Netherlands, phone: +31 24361 1974, fax: +31 24361 2379, email: e.dejong@fm.ru.nl 


\section{INTRODUCTION}

Ownership structures can differ with respect to the degree of ownership concentration and with respect to the type of owners. In the literature, relatively much attention has been paid to the degree of ownership concentration and its effects. In this article we will consider the cross-country differences in type of owners, a less frequently studied but potentially important object. The type of ownership is not only important for the way the owners can control management (the main topic for studies on ownership concentration) but also with respect to the objective of the firm. Firms can have varies objectives, such as a high profit, a dominant position in the market, and continuity of the firm. Although one can safely assume that all these objectives are of more or less importance for every firm, their relative importance can differ significantly between companies.

The identity of the owner is an important explanatory variable for the relative importance of the various objectives of a firm. In general, widely held firms will put relatively much weight on maximizing profits, whereas firms owned by families will put more weight on continuity. This may have consequences for the level of profits, the number of employees, and the type of industry in which each of these types of firms operate. State owned enterprises need not necessarily strive for profit maximization, which can lead to less innovation than the privately held competitors. Another consequence might be that it can build a strategic position in a particular branch. A strategy which might be impossible for privately held companies because of the long period during which one as to face losses or because the governments involved would never allow a privately held company to build such a dominant position. Especially in the literature on transition economies, it is often claimed that firms owned by foreigners increase the level of competition in an economy. So overall one can conclude that the differences in identity of owners can have far reaching consequences for the structure of national economies and its performance.

Several recent cross-country studies have found quite large differences in ownership patterns in different countries. La Porta et al. (1999) report the data on the number of firms with different types of largest ultimate owners within the 20 largest listed firms and ten 'medium-size' firms in 27 countries. Pedersen and Thomsen (1998) present a similar analysis for the 100 largest companies in fourteen European countries. Faccio and Lang (2002) analyze ownership patterns using a sample covering most of the publicly listed firms in thirteen European countries (with coverage ranging from 67 firms in Ireland to 1953 firms in the UK), and Claessens et al. (2002) perform this task for eight East Asian countries.

The previous studies show several shortcomings. First and most obvious, the coverage of even industrialized nations is not comprehensive. Australia, Canada, New Zealand and the USA, are not included in any of the comparative analyses, and Denmark and the Netherlands are not included in an analysis on large samples of firms. The papers differ in the methodology used, the issues addressed, and the data contained in the datasets, so that the figures are comparable only on a very limited range of indicators.

Second, the literature mentioned does not adequately address the influence of the size of firms (and thus of countries) on ownership patterns. There are several reasons to expect that larger firms are widely held and have a smaller probability of being owned by a family. Larger firms need more external capital, which is more difficult to obtain from a limited number of investors. Larger firms are more attractive for investment by arm's-length investors, for several reasons: information disclosure and corporate governance requirements imposed on these firms by the government are usually stricter; larger firms attract more and more detailed analyst following; smaller firms often are focused on one product, process and idea, making investment in them more risky; larger firms tend to be better known, and investment in them may give a feeling of security. Empirically, the fact that larger firms tend to have a less concentrated ownership structure is well established. An important consequence of this is that country differences observed in ownership patterns may in part reflect differences in size of the firms and not true country differences. A comparison of the numbers of firms with different values of the stake of the dominant shareholder within a given number (say, a twenty or hundred) of the largest firms in different countries, as well as comparison of all firms in the sample, may lead to erroneous conclusions. Previous studies addressed this issue, by taking a certain (relatively low) value of firm size and comparing an equal number (ten or fifty) of firms above this cut-off, so that 'small' or 'mediumsized' firms could be compared. This procedure, however, is not really an adequate solution. In countries with a small number of firms in the sample, the largest firm in the 'medium-size' group will be much larger than the largest firm in a country with many firms in the sample. ${ }^{1}$ Hence the conclusions on ownership patterns are then related to size and not to other differences between countries.

1 As an example, La Porta and colleagues compare ten firms with market capitalization immediately above $\$ 500 \mathrm{mln}$. The largest of these ten in our sample in the USA has a market capitalization of $\$ 514 \mathrm{mln}$, and in Portugal - of $\$ 13,060 \mathrm{mln}$. 
Several issues are either not addressed or addressed insufficiently in the studies mentioned above. First, the attention of the cross-country studies has focused on attempting to identify ultimate owners of firms. While this is important, the pattern of direct ownership is no less or even more important for many issues. For instance, if a given investor owns more than 50 percent of voting rights in a firm, this firm cannot be taken over, regardless of whether this investor is a person or a company in which the largest ultimate owner has only 20 percent of votes. Likewise, for large corporations management and monitoring by owners, requires professionalism, and the ultimate third- or fourth-tier owners, if they are individuals, are unlikely to do such monitoring themselves. It would be delegated to the managers of the lower-tier company, and the objectives, capacities and practices of these managers will probably not differ much from those of managers in a widelyheld corporation.

Second, the previous studies emphasize the role of the largest shareholder (or sometimes, for some reason, three largest shareholders as a unit) at the expense of attention to the role of other shareholders and their interaction with the largest shareholders. There are reasons to expect that such interactions would be very important in practice. A large second shareholder may curb the dilution by the largest shareholder. At the same time, if the interests of these shareholders are similar, the largest shareholder may achieve its goals with a lesser ownership stake. Furthermore, the different types of shareholders can differ importantly in their investment objectives. For some investors the return on equity is the only objective. Other investors (families, government, non-financial company) have an association with a firm besides that of equity ownership, and this association may be more important for them than extracting the maximum short-term return on their investment. Thus, in many cases they are likely to demand policies that are not the best from the point of view of arm's-length shareholders. Furthermore, such investors are very unlikely to sell shares to someone who makes a financially attractive offer since the purpose of the shareholding is to cement the other association with the firm. At the same time, by threatening to reduce their stake, these investors may provide a powerful restraint on dilution by the largest shareholder and/or by management.

Third, except for Pedersen and Thomsen (1998) the literature did not pay attention to the industry aspect of ownership patterns. There are reasons to expect that optimal ownership structures differ for firms engaging in different types of economic activities, and thus optimal ownership structures and empirical ownership patterns, in different industries may differ. ${ }^{2}$ Industries can differ with respect to the degree of commitment that is needed from all the stakeholders concerned. Concentrated shareholdings and the presence of stable shareholders such as a family or the state may encourage closer relationships with stakeholders and their commitment. If shareholders are interested in returns of the company over a long period, it will be in their interests to honor their part of implicit relationship obligations and commitments. If, however, they are interested only in short-term returns on their shares, shareholders may well choose not to honor the implicit contracts, redistribute wealth in this way to themselves, and exit the firm (Shleifer and Summers, 1988). Clearly, the latter is more likely to be the case for small shareholders in widely held firms. Moreover the commitment to honoring implicit contracts, is more credible for large block holders, because they cannot exit the firm without substantial decrease in share price and thus without losses to themselves. Thus, they would be more committed to the firm and its long-term prospects (Franks and Mayer, 1994). At the same time, close relationships of shareholders with firms may make it more difficult to go out of commitments with stakeholders when it is necessary for the firm's functioning, and thus may be detrimental for flexibility (Carlin and Mayer, 2002). Theoretical and empirical research indicates that the degree of flexibility needed may differ between industries. Huang and Xu (1999) show theoretically that widely held firms with many arm's-length relationships may be superior in accomplishing projects with high uncertainty of the outcome, while close relationships may be superior for projects with low uncertainty Concentrated ownership and shares in hand of long-term shareholders thus may be more advantageous in industries where the character of activities makes commitment of stakeholders vital, while dispersed ownership patterns may be superior for industries where flexibility is more important and outcomes are more uncertain.

This has several important implications. To the extent country-specific factors impede the formation of certain ownership structures, this may hamper the development of the corresponding industries in this countries. On the other hand, country differences observed in ownership patterns may in part reflect differences in industry composition and not true differences in country-specific factors.

The aim of our research project is to remedy these shortcomings. We construct a dataset covering 24 industrialized nations using a unified methodology, which allows us to come out with analyses covering most of the industrialized world. In this paper we concentrate on the nature of large shareholders, and patterns of direct ownership. ${ }^{3}$ We do not only study country patterns and differences but also the influence of size and industry. In this respect we pay in particular attention to making comparisons on the basis of comparable

2 See Pedersen and Thomsen (1998) for more arguments.

3 In related papers we also want to study the degree of ownership concentration, separation of ownership and control, the role of stable shareholdings, the role of the second shareholder, the relative role of the largest owner and other stable shareholders. 
units. One of our goals is to analyze to what extent differences in size and industry composition impact (and thus distort) the country-level indicators of ownership patterns.

The setup of this paper is as follows. In the next section we briefly describe the dataset used. Section 3 investigates the pattern of types of owners (family, government etc.) among countries and industries. Section 4 contains an econometric analysis relating ownership structures to firm's size, type of industry and country. Six main types of industry are distinguished, and a more in depth analysis is conducted for manufacturing, which itself contains 22 industries. A comparison with previous studies is performed in Section 5. Section 6 concludes.

\section{THE DATASET}

The analysis in this paper is based on a newly constructed dataset for 6668 publicly traded corporations in 24 countries. The primary source of our data is the ownership database of Thomson Banker. Thomson collects this information from a number of sources including, but not limited to, official company-issued statements and the media. We collected the information for the firms in 24 countries; all countries where a sufficient firms with reliable data were present in the database. We collect information for all non-financial firms (onedigit primary SIC code other than 6) with data on ownership, stock market capitalization, and primary SIC code. However, for Japan and the United States, because of the time and cost constraints, we collect information only on one third of the firms present in the database, evenly spread by size and industry. More precisely, in each of these countries we divided the firms into ten groups according to size, within each of these ten groups we arranged the firms by the 4-digit primary SIC code. Within each of these industries (based on 4-digit primary SIC code) we ordered the firms according to size and took every third firm from this list, starting from the third.

In several cases the information in Thomson Banker was not satisfactory. In such cases we augmented the dataset with information from other sources, primarily company websites and annual reports. ${ }^{4}$ In particular, for firms with dual-class shares the information from Thomson Banker is not sufficient, since it reflects the ownership structure of only one class of shares. In many instances (especially in Scandinavia), these are actually the shares with subordinate voting rights, mostly because the shares with full voting rights are not listed. We identify the companies with dual class shares via Datastream. Fifteen companies of this type for which we could not find data from alternative sources are excluded from the sample.

In some cases the total percentage of shareholdings reported by Thomson was greater than $100 \%$. For five of these companies we could not find information from alternative sources and excluded them from the dataset. In some cases the fraction of total shareholding reported by Thomson Banker is quite low, raising doubts about the presence of all substantial shareholders in this dataset. For companies where the fraction of total shareholding reported was less than $10 \%$, we collected information using other sources, and were often able to identify investors holding very substantial fractions of shares. Forty-eight of these companies where we could not find ownership information were excluded from the dataset. Finally, we exclude from the dataset companies where the largest equity stake at the moment of reporting was larger than $20 \%$ and was held by the company itself (four companies) or a broker-dealer firm (five companies). This procedure resulted in a dataset of 6668 firms from 24 industrial countries.

For each firm the dataset includes its industry affiliation, some financial characteristics, and the latest available (in July 2004) data on:

. the percentage of shares owned by the largest shareholder;

. the percentage of shares held and the type of shareholders owning more than 10 percent of shares;

. the percentage of shares held and the type of stable shareholders (holding more than 3 percent of shares) for firms where such shareholders together own more than 20 percent of shares, or where there is a shareholders owning more than 10 percent of shares.

Eight different types of shareholder are distinguished (see Section 3 for details). We treat as stable shareholders all shareholders that hold 3 or more percent of voting rights, except when these shareholders are: insurance companies, pension funds, trusts, 'investment advisors' and broker-dealers. To identify ultimate ownership patterns, we also collected, using the same procedure, the information on all listed firms - financial as well as non-financial - that are not included in the main dataset but are shareholders in the firms in the main dataset. These firms themselves, however, are not included in our analysis.

4 Additional sources of information include: for Belgium, France, the Netherlands and Portugal, Euronext (www.euronext.com); for Germany, http://ir-service.onvista.de; for Italy, the website of the securities markets authority (www.consob.it). For Canadian and US firms, additional information was collected from annual reports and proxy statements available on websites of securities markets authorities (www.sedar.com and www.sec.gov). 
In the rest of the paper we use the following convention: if the largest shareholder of a firm has more than $20 \%$ of voting rights, this shareholder is called dominant; if this shareholder has more than $50 \%$ of voting rights, this shareholder is called majority shareholder.

\section{TYPES OF OWNERS}

In this section we analyze the ownership patterns by owner types. The following eight ownership types are distinguished:

Family. An individual or family.

Listed non-financial company. A domestic listed non-financial firm.

Government. A national or regional government authority (domestic or foreign) or government agency.

Foreign. A company with a foreign business address.

Institutional investor. Investment fund, bank trust, pension fund, or insurance company.

Bank. A bank holding shares on its own accord.

Non-profit. A non-profit organization (charity, foundation, cooperative).

Unlisted company. A domestic company not listed on stock exchange. This category includes all the firms classified as 'corporations' by Thomson Financial (and thus may include both non-financial and financial firms), and private equity funds and venture firms.

\section{< Insert Table 1 and Table 2>}

Table 1 shows the number of firms of different types in each country and Table 2 presents the percentages of these firms, relative to the country totals. Widely held firms, family-controlled firms and firms controlled by an unlisted company are by far the most important types of companies in the sample and are the three most important categories in 16 countries, and among the four most important categories in five further countries. Slightly less than 50 percent of the firms in the sample are widely held. The percentage varies from nine percent in Hong Kong to 74 percent in Ireland. Nineteen percent of firms are under direct family control, with variation from three percent (in Portugal) to 43 percent (in Italy). In Portugal almost 60 percent of firms are controlled by an unlisted company, while in Ireland there are no such firms. Control by listed non-financial companies is important in Israel, Japan, Portugal, and Spain. Foreign-controlled firms are relatively prominent in Belgium, Germany, Hong Kong, Ireland, the Netherlands, New Zealand, and Switzerland. The state is a significant shareholder in some firms in all countries except Canada, Ireland, Portugal and the USA. In Austria, Italy, and Singapore government-controlled firms are relatively important. In Denmark, firms with a non-profit organization as a dominant owner play an important role. In no country do banks and institutional investors play an important role as a dominant shareholder.

We also look at indirect ownership. To this purpose we identified the dominant owners of the listed domestic non-financial companies. When these are listed domestic companies themselves, we identified their dominant owners, till we came to a dominant owner that is not a listed company or to a situation when there is no dominant owner. In the former case we classified the firm as (indirectly) controlled by this dominant owner; if this owner is a family, the firm is classified as (indirectly) controlled by a family, etc. In the latter case we classified the firm as controlled by widely held non-financial firm. Furthermore, following the previous literature (La Porta et al.; Claessens et al.; Fascio and Lang) we classified unlisted companies as family-controlled firms.

Of the 355 listed non-financial companies controlling other companies in our sample, there are 241 which are themselves ultimately widely held, 38 are controlled by a family, 46 by an unlisted company, 12 by the government, six by a foreign agent, two by an institutional investor, another two by a non-profit organization, and one by a bank. For eight listed companies controlling the companies in the sample we could not trace owners, and exclude them from the analysis of second-tier ownership patterns.

\section{< Insert Table 3 and Table 4>}

Table 3 shows the numbers of firms of different types in each country, and Table 4 the percentages of these firms, relative to the country totals. Widely held firms or firms directly or indirectly controlled by families are the two most important categories in all countries except Hong Kong, where there are more foreign-controlled firms than widely held firms. Families directly or indirectly control 38 percent of the firms, ranging from 11 percent in Ireland to 78 percent in Portugal. Interestingly, Portugal has the lowest percentage of all countries of firms directly controlled by families. Control by widely held non-financial firms is much more prominent in Japan than elsewhere, and in Israel, Korea and Spain this type of shareholder is also important. The inferences for other types of shareholders are similar to those made in analyzing direct ownership. 


\section{$<$ Insert Table 5>}

Table 5 shows the percentages of large (top quintile), medium (third quintile), and small (bottom quintile) firms with dominant shareholders of different types. The proportion of widely held firms monotonically increases with size in Australia, Canada, France, Germany, Hong Kong, Japan, Korea, the Netherlands, the UK, and the USA, but monotonically decreases in Ireland, Israel, Portugal, Singapore, Sweden, and Switzerland. Only in 13 of 24 countries are large firms more likely to be widely held than small firms. Proportion of family controlled firms monotonically decreases with size in Australia, France, Germany, Hong Kong, Ireland, Japan, Korea, the Netherlands, Norway, the UK, and the USA. Only in Austria, Finland, Israel, and Portugal are large firms more likely to be controlled by a family than small firms. Proportion of firms controlled by an unlisted company monotonically increases with size in Austria, Finland, France, Japan, Korea, the Netherlands, New Zealand, Portugal, Singapore, and the UK, but monotonically decreases in Ireland, Italy and Sweden. In 17 of the 24 countries large firms are more likely to be controlled by an unlisted company than small firms. In the sample as a whole, and in twelve of the countries, listed companies are more (often much more) likely to be dominant owners of large firms than of small or medium firms. In all countries the government ownership is more prominent in large than in small companies; Austria, Denmark, Finland, Portugal, and Singapore the state plays a very prominent role in the ownership of this group of firms. Except in New Zealand and Singapore, dominant ownership by institutional investors is concentrated on small and medium companies. Banks are dominant owners only in small and medium companies, except in Spain, where they are dominant owners of both small and large firms. Non-profit organizations, in contrast, tend to concentrate on large companies. In 16 countries direct and indirect ownership by families monotonically decreases with size, and in all countries except Italy families are more likely to directly or indirectly control small firms than large firms.

\section{PATTERNS OF OWNERSHIP AND TYPE OF INDUSTRY}

Is there a relationship between the patterns of ownership and the industry affiliation? In analyzing ownership patterns, we run individual-country maximum likelihood logit estimations of the type

$$
Y_{j k}=\alpha \cdot M C_{j k}+\sum_{j} \beta_{j} \cdot I_{j}+\varepsilon_{j k}
$$

where $Y_{j k}$ is the ownership indicator, $M C_{j k}$ is the $\log$ of stock market capitalization, and $I_{j}$ are industry dummies; where the index k refers to the company, $j$ the industry and $i$ the country concerned. A full set of industry dummies is included. We also run pooled cross-country estimations of the equation

$$
Y_{i j k}=\alpha \cdot M C_{i j k}+\sum_{j} \beta_{j} \cdot I_{j}+\sum \gamma_{i} \cdot C_{i}+\varepsilon_{j k},
$$

where $C_{i}$ are country dummies; the dummy for Japan is not included. In order to avoid the excessive influence of countries with the large number of firms in the sample, the regressions we run on the whole sample are weighted, with weights inversely proportional to the percentage of firms in the sample (and scaled so that the resulting number of observations is the same). This procedure ensures that in estimating the regressions the number of observations per country effectively is equal. Both in the regressions with and without country dummies market capitalization is a significant predictor of the probability of having the controlling shareholder.

\section{< Insert Table 6>}

Table 6 reports the results for widely-held firms. The regressions confirm that larger firms are more likely to be widely held: for all but three countries the coefficient of the log of market capitalization (column heading 'size') is positive, and for eleven countries it is significant at the 10 percent level. The whole-sample regressions indicate that firms in utilities are significantly less likely to be widely held than firms in all other industries, while firms in services are significantly more likely to be widely held than firms in all other industries except mining and construction, without significant differences among agriculture, mining and construction, manufacturing, and trade sector. In 13 of the 21 countries in which utilities industry is included in the estimations either there are no widely held firms in utilities industry, or the coefficient of the utilities dummy is the smallest among all coefficients; in three more countries it is the second smallest. On the other hand, in services the coefficient of dummies is among the two largest coefficients in twelve countries. However, it is among the two smallest coefficients only in four countries (among which are Japan and the USA). Mining and construction firms are significantly more likely to be widely held than firms in some other industries in four countries (counting the cases when no firms in a country in a given industry are widely held), but are significantly less likely to be widely held than firms in some other industries in five countries. 
For manufacturing, the corresponding numbers are nine and seven countries; for utilities, two and nine; for trade sector, three and seven; and for services, six and four countries.

\section{$<$ Insert Table 7>}

The results for direct control by families are reported in Table 7. In Portugal, all firms in the sample with market capitalization of $\$ 190 \mathrm{mln}$ or less (that is about a half of the number of firms in our sample) are familycontrolled, while firms above this size are not. In 12 of the other 23 countries larger firms are significantly more likely to be family-controlled. Firms in utilities are least likely to be family controlled, followed by mining and construction; in agriculture, manufacturing, trade sector and services family control is more prevalent, without significant differences among these four industries. In 18 of the 21 countries there are no firms in utilities that are family controlled, or the coefficient of the dummy is among the two smallest coefficients. The same is true for mining for 14 of the 19 countries.

\section{<Insert Table 8>}

Table 8 presents the results for direct control by unlisted companies. The whole-sample regressions do not include firms from Ireland where there are no firms controlled by an unlisted company. In all but two countries the size-coefficient is negative. Control by unlisted companies is most prevalent in utilities and trade sector, followed by manufacturing; mining and construction; and agriculture and services. The coefficient of the utility dummy is among the two largest coefficients in 15 of the 21 countries where it is included, and the coefficient of the trade sector dummy: in 13 of the 21 countries. In 16 of the 23 countries either there are no firms in services that are controlled by an unlisted company, or the coefficient of the dummy is among the two smallest coefficients.

\section{$<$ Insert Table 9>}

There are too few firms of other types to conduct individual country regressions. The results of whole-sample regressions are presented in Table 9. Control by listed non-financial companies is more usual in larger firms, and is most prevalent in agriculture, followed by utilities. In foreign control regressions, many coefficients are significant at the level between 10 and 15 percent, so that it is difficult to detect a pattern. Firms in the trade sector have a foreign controlling shareholder least often, followed by manufacturing. In other industries we are about equally likely to encounter a foreign owner.

Governments tend to be controlling shareholders of larger firms and are by far most important in utilities, and least important in trade, with little differences between other industries. Out of the 103 firms where the state is the dominant shareholder, 53 are in utilities. The only Danish firm where the state is the dominant shareholder is in this industry, as are the only British firm, the only Israeli firm and the only two Swedish firms. Still, in 16 countries the state is the dominant shareholder also in firms in other industries, in fact in all industry sectors. One firm is in agriculture (a Hong Kong based firm involved in raw wood production), two (in France and Korea) in construction, one company is a property developer listed in Australia but owned by the government of Singapore, and one (Australian pharmaceuticals producer and distributor) has the trade sector as the main industry. Ten firms are in service sector, six of which are in Singapore (including hotels, medical services, supply chain management, computer systems development). ${ }^{5}$ Thirty-five firms are in manufacturing, including eight in Singapore, five in Finland, five in Korea and four in Hong Kong. The utilities firms owned by the state tend to be large, with 30 of the 53 firms in the top quintile of the total sample distribution, and all but seven firms in the top two quintiles. Firms in other industries also tend to be large, with 22 of the 50 firms in the top quintile of the total sample distribution, and 36 firms in the top two quintiles.

Institutional investors are more likely to control smaller firms, and firms in manufacturing, and to some extent services. Almost three-quarters of the firms controlled by institutional investors come from Canada, the UK and the USA. The Canadian firms tend to be small (eight of the 13 are in the bottom two quintiles of the total sample distribution) and come disproportionately from mining and construction and construction (six of the 13 firms). The British firms tend not to be very large (only three firms in the top quintile of the total sample distribution) but otherwise evenly spread by size, and to come somewhat more often than on average in this country from manufacturing and somewhat less often from mining and construction and utilities. The US firms likewise tend not to be very large (only two firms in the top quintile of the total sample distribution, where in the whole sample the US firms are heavily overrepresented) but are

5 Services firms in other countries are a plant and housing development firm in Korea, a casinos firm in France, a hotel in Switzerland, and an infrastructure management firm in the Netherlands. 
otherwise evenly spread by size. Their industry distribution is quite similar to the overall distribution of the US firms, but with utilities industry having a somewhat lower presence. Firms controlled by institutional investors in other countries are generally small (21 of the 30 firms are in the bottom two quintiles of the total sample distribution). These firms come more often from manufacturing and less often from utilities and services.

Firms owned by banks are spread across industries. ${ }^{6}$ Only two firms belong to the high technology industries. The companies owned by banks tend to be small, with eight of the 22 firms in the bottom quintile of the total sample distribution, and only six firms in the top two quintiles.

Non-profit organizations are dominant owners in eleven firms in Denmark, five in Sweden, and sixteen firms in ten other countries. The Danish firms come from every single industry (except agriculture) and are quite evenly spread by size. The Swedish firms are also of different sizes and come from different industries (construction, manufacturing, trade and services). Firms in other countries with a non-profit organization as a dominant owner tend to be relatively large: six of the 16 firms are in the top quintile of the total sample distribution. All but two of the 16 firms are in manufacturing.

\section{$<$ Insert Table 10>}

Turning to the analysis of direct and indirect shareholders, as we can see in the last rows of Table 9, widely held firms are more important as dominant owners in larger companies and in utilities firms. Table 10 shows the results for firms directly or indirectly controlled by families. In all countries such control is more likely for smaller firms, in 17 of the 24 countries significantly so. In the sample as a whole, firms in the trade sector are more likely to be family controlled than firms in manufacturing and agriculture, which in turn are more likely to be family controlled than firms in other industries. In 16 of the 22 countries where the trade sector is included, either all firms in this sector are family controlled or the coefficient of the dummy is among the two largest coefficients For manufacturing, however, this is true only for 9 of the 24 countries.

\section{<Insert Table 11>}

In order to inquire whether the importance of different types of owners differ between manufacturing industries, we run the whole-sample regression that in addition to the usual variables include dummies for 21 manufacturing industries. Table 11 shows the coefficients of these dummies. It is not practical to test the equality of every single pair of coefficients. One would generally expect that either there is no difference in coefficients, or a certain number of smallest (largest) coefficients would differ significantly from the largest (smallest) coefficient, a smaller number of coefficients would differ from the second largest (smallest) coefficient and so on, with exceptions depending on the size of industries. The most interesting question is whether there is a difference in coefficients, in particular a difference not caused by one or two possible extreme coefficients. We choose first to compare the significance levels of coefficients equally distant from the extremes (the smallest and the largest coefficient, the second smallest and the second largest, etc.), and then test the equality of coefficients close to those of the first pair for which the coefficients are not significantly different. In this way we arrive at two groups of firms, one with the smallest coefficients of their dummies and one with the largest coefficients, the coefficients of members of which significantly differ from each other (at 10 percent level). In practice such groups in all cases comprise from 5 to 7 industries each. The likelihood of having a controlling shareholder of a certain type is thus statistically significantly higher in certain manufacturing industries than in others, and this is not caused by an extreme character of one or two industries. An alternative would be to test the difference from the largest and smallest coefficient (based on tests for two of the regressions, about half of coefficients differ significantly from the extreme coefficient) or from the median coefficient (two to four most extreme coefficients show significant differences in this case).

It is interesting to look at high-technology industries: aircraft, computers, instruments, communication equipment, pharmaceuticals, chemicals, electrical machinery. As a rule most, but not all of these industries tend to be close to one of the ends of the range of industries for a given type of shareholder. Widely held firms are more prevalent in all these industries except aircraft than in any other industry except non-metal products. All industries except pharmaceuticals are among the nine industries where direct or indirect control by families is least present. Aircraft, chemicals, communication equipment and electrical machinery are less likely to be directly controlled by a family than any other industry except petroleum. Computing, communication equipment, and electrical machinery, are among the four industries where firms are least likely to be controlled by a foreign shareholder, with instruments at the eighth place. On the other

6 Three are in agriculture, one in mining and construction, three in utilities, one in trade, five in services, and eleven in manufacturing. The manufacturing firms belong to different sub-industries. Two firms are in the food sector. 
hand aircraft is the industry which is most likely to have a dominant foreign owner. Electrical machinery, pharmaceuticals, computing, and communication equipment are among the nine industries where firms are least likely to be controlled by a listed non-financial firm.

Among other industries, food has disproportionately many firms controlled by listed companies and few firms controlled by unlisted companies. Firms in clothing are not very likely to be controlled by listed (in particular, widely held) companies or by foreigners. Wood industry has few widely held firms, firms controlled by unlisted companies, and firms controlled by widely held companies, but relatively many firms with foreigners as dominant shareholders. Firms in paper industry are less often widely held or controlled by listed (in particular, widely held) companies than on average. Disproportionately many firms in printing industry are controlled by families, unlisted companies, and foreigners. Few of the printing firms are widely held. Firms in petroleum industry, other things equal, are less likely than firms in any other industry to be widely held or be controlled by unlisted companies, and less likely than firms in any other industry except aircraft to be directly controlled by families. Listed (in particular, widely held) companies and unlisted companies control a larger than average share of rubber and plastics firms. Basic metals industry is characterized by strong presence of widely held companies as controlling shareholders, and little role for foreign agents.

Other types of shareholders control too few firms for the estimations of the type presented in Table 11 to be feasible. Out of the 35 manufacturing firms controlled by a government, six firms (in Austria, Finland, Italy, Norway, Singapore, and Spain) are in petroleum industry, five (in Finland, Germany, Korea and Norway) - in primary metals, and four (in Korea, New Zealand and Singapore) - in shipbuilding. There are also state-owned firms in food, tobacco, paper, printing, chemicals, electrical machinery, communication equipment, motor vehicles, aircraft, and instrument industries. Firms controlled by institutional investors and banks are spread across different manufacturing industries.

To summarize our findings, larger firms are more likely to be widely held and are more likely to be controlled by listed non-financial companies (in particular, widely held companies) and governments, whereas smaller firms are more likely to be have a family, an unlisted company, an institutional investors, or a bank as the dominant shareholder. Firms in manufacturing are less likely to be controlled by listed non-financial companies than firms in all other industries, less likely to have a foreigner as the dominant shareholder than firms in most other industries, but control by institutional investors is more prevalent in this industry than in most others. Firms in utilities are significantly less likely to be widely held and significantly less likely to be directly family-controlled than firms in other industries, but are more likely to be controlled by a government, a listed non-financial company (in particular, a widely held company), or by an unlisted company. Firms in services are more likely to widely held, and less likely to be controlled by an unlisted company, than firms in most other industries. Control by governments and foreigners plays a smaller role in trade sector than in other industries, but control by unlisted companies is relatively prevalent. Firms in mining and construction are relatively rarely controlled by families. Firms in agriculture are more likely to be controlled by listed nonfinancial companies and are never controlled by institutional investors and widely held non-financial companies.

\section{COMPARISON WITH OTHER STUDIES}

A great advantage of our study is that it contains more information than most of the other studies. Our sample differs in sample coverage (in particular, exclusion of financial firms and lower size cut-off), the extent of identification of ultimate owners, and the definition of some categories (in particular, previous authors do not include a separate category for foreign owners and treat financial institutions somewhat differently from us). The differences with the studies by Faccio and Lang (2002) and Claesens et al. (2000) are presented in Table 12 .

\section{< Insert Table 12>}

For European countries our figures for direct and indirect ownership generally are quite similar to those reported by Faccio and Lang regarding ownership by state and by widely held corporations, and also for the percentage of widely held and family-controlled firms for Belgium, France, Italy, Norway, Sweden, and the UK. We identify somewhat lower percentage of widely held firms in Portugal, somewhat higher percentage of widely held firms in Austria, Finland, Germany, Ireland, Switzerland and especially Spain. In our sample, there are less family-controlled firms than in the Faccio-Lang sample in Germany, Ireland, Portugal, Spain, and Switzerland. These differences may stem from exclusion of smaller firms from our sample, which are less likely to be widely held and more likely to be family-controlled, and/or from evolution of ownership patterns, with more firms becoming widely held. Claessens et al. report figures generally similar to ours for Hong Kong, Korea, and Singapore. We find a somewhat lower incidence of family control in Korea and a higher 
percentage of widely held firms in Singapore. The results for Japan, however, differ considerably. Claessens et al. report that 80 percent of Japanese firms in their sample are widely held, 10 percent are family controlled, 3 percent are controlled by widely held non-financial companies, and 6.5 percent by widely held financial institutions. The corresponding figures in our analysis are 61, 20, 16, and 0.2 percent (for banks and institutional investors). These differences may stem, in particular, from the inclusion of financial firms in the sample of Claessens et al.

\section{<Insert Table 13>}

Table 13 reports the figures for the 20 largest firms in our sample. Comparing them with the findings of La Porta et al. (1999), we observe that the figures often do not differ significantly from each other. The major difference is the much lower incidence of state-controlled firms in our sample, especially in Austria, Finland, Germany, Israel, New Zealand, and Portugal, and to a lesser extent in Finland and Italy, which is likely to be related to the evolution of ownership patterns. In Australia, Canada, and New Zealand we find a much lower incidence of control by widely held companies (although these controlling companies in the sample of La Porta et al. may be foreign; we find some incidence of foreign control in our sample). We find a significantly higher percentage of widely held firms in Finland, Germany and the Netherlands than La Porta and his colleagues, and much higher incidence of family control in Italy and Potugal. The correlation coefficient between the two samples of the percentage of widely held firms is 0.91 , of the percentage of family-controlled firms is 0.75 , and of the percentage of state-controlled firms is 0.75 .

\section{<Insert Table 14>}

Table 14 reports the figures for the 10 'medium-size' firms in our sample, selected in the same way as is done by La Porta et al. The comparison with the figures reported by La Porta et al. suggests that the two sets of figures generally exhibit similar patterns. Again, the most striking difference is a much smaller incidence of government control in our sample, in particular in France, Germany, Israel, Portugal, Spain, Sweden, and especially Austria, where 83 percent of the firms were state controlled, as opposed to none in our sample. It is not surprising that in these countries we find a higher incidence of either widely held firms (in Austria, France, Israel, Spain, Sweden) or family-controlled firms (in France, Germany, Portugal, and Spain). Other main differences are a comparatively greater prominence in our sample of widely held firms and a smaller role of family-controlled firms in Hong Kong and Korea, a greater importance of family-controlled firms in Belgium, and a larger role of family-controlled firms compared to widely held firms in the USA (in the sample of La Porta et al. nine of the ten firms were widely held and one was family controlled, while in our sample this holds for correspondingly six and four firms). The correlation coefficients this time are somewhat lower, between 0.49 and 0.67 .

\section{CONCLUSIONS}

This paper has investigated the identity of ownership of slightly less than 7000 firms in 24 industrial countries. Attention as been paid to the size of the firms, the industry it belongs to, and the country concerned. Almost 50 percent of the firms are widely held. Families and unlisted companies are the owners of 19 respectively 17 percent of the companies. In all countries banks and institutional investors hold only small percentage of the companies. Except for Denmark, the same holds for non-profit organizations. Listed nonfinancial firms, foreigners and the government constitute the medium group. The differences between the countries can be quite substantial.

The logit regressions reveal that larger firms are more likely to be widely held and are more likely to be controlled by listed non-financial companies and governments, whereas smaller firms are more likely to have a family, an unlisted company, an institutional investor, or a bank as the dominant shareholder. Firms in manufacturing are less likely to be controlled by listed non-financial companies than firms in all other industries, but control by institutional investors is more prevalent in this industry than in most others. Firms in utilities are more likely to be controlled by a government or a non-financial company (both listed and unlisted). Firms in services are more likely to widely held. In the trade sector control by unlisted companies is relatively prevalent. Firms in mining and construction are relatively rarely controlled by families. Firms in agriculture are more likely to be controlled by listed non-financial companies and are never controlled by institutional investors and widely held non-financial companies.

We consider these results as a good basis for future research, which should go more deeply in the explanatory factors and the consequences of the ownership structures found. 


\section{REFERENCES}

Carlin, W., and Mayer, C., 2002, Finance, investment, and growth, mimeo, University College London and Said Business School, University of Oxford.

Claessens, S., Djankov, S., and Lang, L.H. P., 2000. The separation of ownership and control in East Asian corporations. Journal of Financial Economics 58, 81-112.

Faccio, M., and Lang, L.H.P., 2002. The ultimate ownership of Western European corporations. Journal of Financial Economics 65, 365395.

Franks, J., and Mayer, C., 1994. Ownership and control, in: Siebert, H. (Ed.), Trends in Business Organization: Do Participation and Cooperation Increase Competitiveness?. Mohr Siebeck, Tübingen.

Huang, H., and Xu G., 1999. Institutions, Innovations, and Growth. American Economic Review 89(2), 438-443.

La Porta, R., Lopez-de-Silanes, F., Shleifer, and A., Vishny, R.W., 1999. Corporate ownership around the world. Journal of Finance 54, 471-517.

Pedersen, T., and Thomsen, S., 1998. Industry and ownership structure, International Review of Law and Economics 15 358-402.

Shleifer, A., and Summers, L.H., 1988. Breach of trust in hostile takeovers, in: Auerbach, A.J. (Ed.), Corporate Takeovers: Causes and Consequences. University of Chicago Press, Chicago, 33-56. 
Table 1

Direct control of publicly held firms: numbers of firms

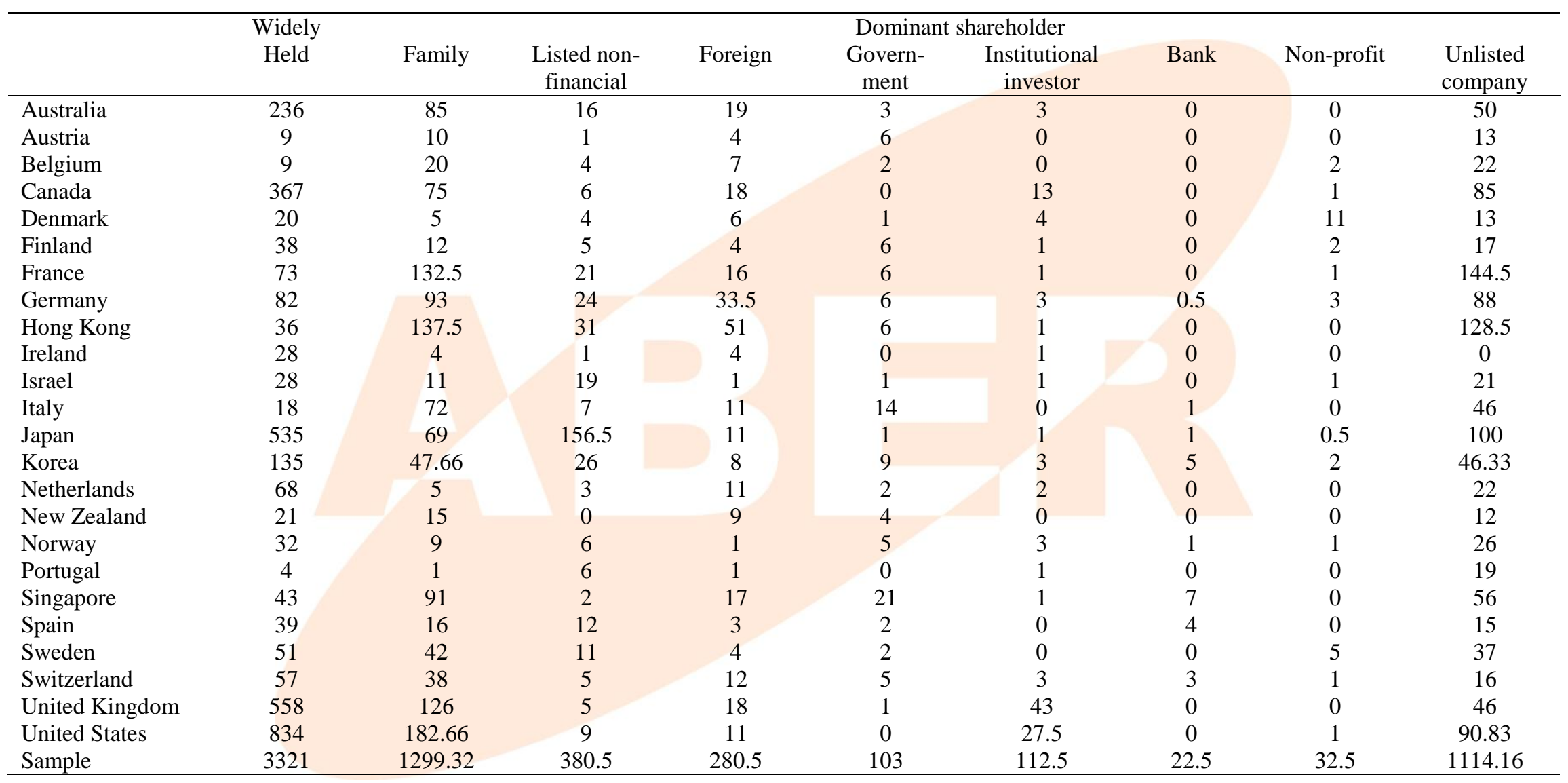

The figures are not always whole numbers since some companies have two or three dominant shareholders of different types. These shareholders were assigned the weights of 0.5 (respectively 0.33 ) in calculating the numbers in the table. 
Table 2

Direct control of publicly held firms: percentages of firms in a country

\begin{tabular}{|c|c|c|c|c|c|c|c|c|c|}
\hline & \multirow{2}{*}{$\begin{array}{l}\text { Widely } \\
\text { Held }\end{array}$} & \multicolumn{8}{|c|}{ Dominant shareholder } \\
\hline & & Family & $\begin{array}{l}\text { Listed non- } \\
\text { financial }\end{array}$ & Foreign & $\begin{array}{c}\text { Govern- } \\
\text { ment }\end{array}$ & $\begin{array}{c}\text { Institutional } \\
\text { investor }\end{array}$ & Bank & Non-profit & $\begin{array}{l}\text { Unlisted } \\
\text { company }\end{array}$ \\
\hline Australia & 57 & 21 & 4 & 5 & 1 & 1 & 0 & 0 & 12 \\
\hline Austria & 21 & 23 & 2 & 9 & 14 & 0 & 0 & 0 & 30 \\
\hline Belgium & 14 & 30 & 6 & 11 & 3 & 0 & 0 & 3 & 33 \\
\hline Canada & 65 & 13 & 1 & 3 & 0 & 2 & 0 & 0 & 15 \\
\hline Denmark & 31 & 8 & 6 & 9 & 2 & 6 & 0 & 17 & 20 \\
\hline Finland & 45 & 14 & 6 & 5 & 7 & 1 & 0 & 2 & 20 \\
\hline France & 18 & 33 & 5 & 4 & 2 & 0 & 0 & 1 & 36 \\
\hline Germany & 25 & 28 & 7 & 10 & 2 & 1 & 0 & 1 & 26 \\
\hline Hong Kong & 9 & 35 & 8 & 13 & 2 & 0 & 0 & 0 & 33 \\
\hline Ireland & 74 & 11 & 3 & 11 & 0 & 3 & 0 & 0 & 0 \\
\hline Israel & 34 & 13 & 23 & 1 & 1 & 1 & 0 & 1 & 25 \\
\hline Italy & 11 & 43 & 4 & 7 & 8 & 0 & 1 & 0 & 27 \\
\hline Japan & 61 & 8 & 18 & 1 & 0.1 & 0 & 0 & 0 & 11 \\
\hline Korea & 48 & 17 & 9 & 3 & 3 & 1 & 2 & 1 & 16 \\
\hline Netherlands & 60 & 4 & 3 & 10 & 2 & 2 & 0 & 0 & 19 \\
\hline New Zealand & 34 & 25 & 0 & 15 & 7 & 0 & 0 & 0 & 20 \\
\hline Norway & 38 & 11 & 7 & 1 & 6 & 4 & 1 & 1 & 31 \\
\hline Portugal & 13 & 3 & 19 & 3 & 0 & 3 & 0 & 0 & 59 \\
\hline Singapore & 18 & 38 & 1 & 7 & 9 & 0 & 3 & 0 & 24 \\
\hline Spain & 43 & 18 & 13 & 3 & 2 & 0 & 4 & 0 & 16 \\
\hline Sweden & 34 & 28 & 7 & 3 & 1 & 0 & 0 & 3 & 24 \\
\hline Switzerland & 41 & 27 & 4 & 9 & 4 & 2 & 2 & 1 & 11 \\
\hline United Kingdom & 70 & 16 & 1 & 2 & 0.1 & 5 & 0 & 0 & 6 \\
\hline United States & 72 & 16 & 1 & 1 & 0 & 2 & 0 & 0.1 & 8 \\
\hline Sample & 49.8 & 19 & 6 & 4 & 2 & 2 & 0 & 0 & 17 \\
\hline
\end{tabular}


Table 3

Direct and indirect control of publicly held firms: numbers of firms

\begin{tabular}{|c|c|c|c|c|c|c|c|c|}
\hline & \multirow{2}{*}{$\begin{array}{l}\text { Widely } \\
\text { Held }\end{array}$} & \multicolumn{7}{|c|}{ Dominant shareholder } \\
\hline & & Family & $\begin{array}{c}\text { Widely held } \\
\text { non-financial }\end{array}$ & Foreign & $\begin{array}{c}\text { Govern- } \\
\text { ment }\end{array}$ & $\begin{array}{c}\text { Institutional } \\
\text { investor }\end{array}$ & Bank & Non-profit \\
\hline Australia & 236 & 137 & 13 & 19 & 4 & 3 & 0 & 0 \\
\hline Austria & 9 & 23 & 1 & 4 & 6 & 0 & 0 & 0 \\
\hline Belgium & 9 & 44 & 2 & 7 & 2 & 0 & 0 & 2 \\
\hline Canada & 367 & 162 & 4 & 18 & 0 & 13 & 0 & 1 \\
\hline Denmark & 20 & 19 & 2 & 7 & 1 & 4 & 0 & 11 \\
\hline Finland & 38 & 29 & 3 & 6 & 6 & 1 & 0 & 2 \\
\hline France & 73 & 282 & 11 & 19 & 8 & 1 & 0 & 2 \\
\hline Germany & 82 & 189 & 9 & 37.5 & 9 & 3 & 0.5 & 3 \\
\hline Hong Kong & 36 & 291 & 6 & 51 & 6 & 1 & 0 & 0 \\
\hline Ireland & 28 & 4 & 1 & 4 & 0 & 1 & 0 & 0 \\
\hline Israel & 28 & 45 & 7 & 1 & 1 & 1 & 0 & 1 \\
\hline Italy & 18 & 118 & 4 & 11 & 16 & 0 & 1 & 0 \\
\hline Japan & 535 & 173.5 & 139 & 15 & 3 & 1 & 1 & 0.5 \\
\hline Korea & 135 & 100 & 18 & 10 & 9 & 3 & 5 & 2 \\
\hline Netherlands & 68 & 27 & 2 & 12 & 2 & 2 & 0 & 0 \\
\hline New Zealand & 21 & 27 & 0 & 9 & 4 & 0 & 0 & 0 \\
\hline Norway & 32 & 38 & 2 & 1 & 6 & 3 & 1 & 1 \\
\hline Portugal & 4 & 25 & 1 & 1 & 0 & 1 & 0 & 0 \\
\hline Singapore & 43 & 147 & 1 & 17 & 22 & 1 & 7 & 0 \\
\hline Spain & 39 & 34 & 6 & 5 & 2 & 0 & 5 & 0 \\
\hline Sweden & 51 & 83 & 2 & 5 & 2 & 2 & 0 & 7 \\
\hline Switzerland & 57 & 55 & 2 & 14 & 5 & 3 & 3 & 1 \\
\hline United Kingdom & 558 & 174 & 0 & 20 & 1 & 43 & 0 & 0 \\
\hline United States & 834 & 274.5 & 4 & 15 & 0 & 27.5 & 0 & 1 \\
\hline Sample & 3321 & 2501 & 240 & 308.5 & 115 & 114.5 & 23.5 & 34.5 \\
\hline
\end{tabular}


Table 4

Direct and indirect control of publicly held firms: percentages of firms in a country

\begin{tabular}{|c|c|c|c|c|c|c|c|c|}
\hline \multirow{2}{*}{\multicolumn{2}{|c|}{$\begin{array}{c}\text { Widely } \\
\text { Held }\end{array}$}} & \multirow[b]{2}{*}{ Family } & \multicolumn{4}{|c|}{ Dominant shareholder } & \multirow[b]{2}{*}{ Bank } & \multirow[b]{2}{*}{ Non-profit } \\
\hline & & & $\begin{array}{c}\text { Widely held } \\
\text { non-financial }\end{array}$ & Foreign & $\begin{array}{c}\text { Govern- } \\
\text { ment }\end{array}$ & $\begin{array}{c}\text { Institutional } \\
\text { investor }\end{array}$ & & \\
\hline Australia & 57 & 33 & 3 & 5 & 1 & 1 & 0 & 0 \\
\hline Austria & 21 & 53 & 2 & 9 & 14 & 0 & 0 & 0 \\
\hline Belgium & 14 & 67 & 3 & 11 & 3 & 0 & 0 & 3 \\
\hline Canada & 65 & 29 & 1 & 3 & 0 & 2 & 0 & 0.2 \\
\hline Denmark & 31 & 30 & 3 & 11 & 2 & 6 & 0 & 17 \\
\hline Finland & 45 & 34 & 4 & 7 & 7 & 1 & 0 & 2 \\
\hline France & 18 & 71 & 3 & 5 & 2 & 0.3 & 0 & 1 \\
\hline Germany & 25 & 57 & 3 & 11 & 3 & 1 & 0.2 & 1 \\
\hline Hong Kong & 9 & 74 & 2 & 13 & 2 & 0.3 & 0 & 0 \\
\hline Ireland & 74 & 11 & 3 & 11 & 0 & 3 & 0 & 0 \\
\hline Israel & 33 & 54 & 8 & 1 & 1 & 1 & 0 & 1 \\
\hline Italy & 11 & 70 & 2 & 7 & 10 & 0 & 1 & 0 \\
\hline Japan & 62 & 20 & 16 & 2 & 0.3 & 0.1 & 0.1 & 0.1 \\
\hline Korea & 48 & 35 & 6 & 4 & 3 & 1 & 2 & 1 \\
\hline Netherlands & 60 & 24 & 2 & 11 & 2 & 2 & 0 & 0 \\
\hline New Zealand & 34 & 44 & 0 & 15 & 7 & 0 & 0 & 0 \\
\hline Norway & 38 & 45 & 2 & 1 & 7 & 4 & 1 & 1 \\
\hline Portugal & 13 & 78 & 3 & 3 & 0 & 3 & 0 & 0 \\
\hline Singapore & 18 & 62 & 0.4 & 7 & 9 & 0.4 & 3 & 0 \\
\hline Spain & 43 & 37 & 7 & 5 & 2 & 0 & 5 & 0 \\
\hline Sweden & 34 & 55 & 1 & 3 & 1 & 1 & 0 & 5 \\
\hline Switzerland & 41 & 39 & 1 & 10 & 4 & 2 & 2 & 1 \\
\hline United Kingdom & 70 & 22 & 0 & 3 & 0.1 & 5 & 0 & 0 \\
\hline United States & 72 & 24 & 0.3 & 1 & 0 & 2 & 0 & 0.1 \\
\hline Sample & 50 & 38 & 4 & 5 & 2 & 2 & 0.4 & 1 \\
\hline
\end{tabular}


Table 5

Direct control of publicly held firms and firm size: percentage of firms in country and group

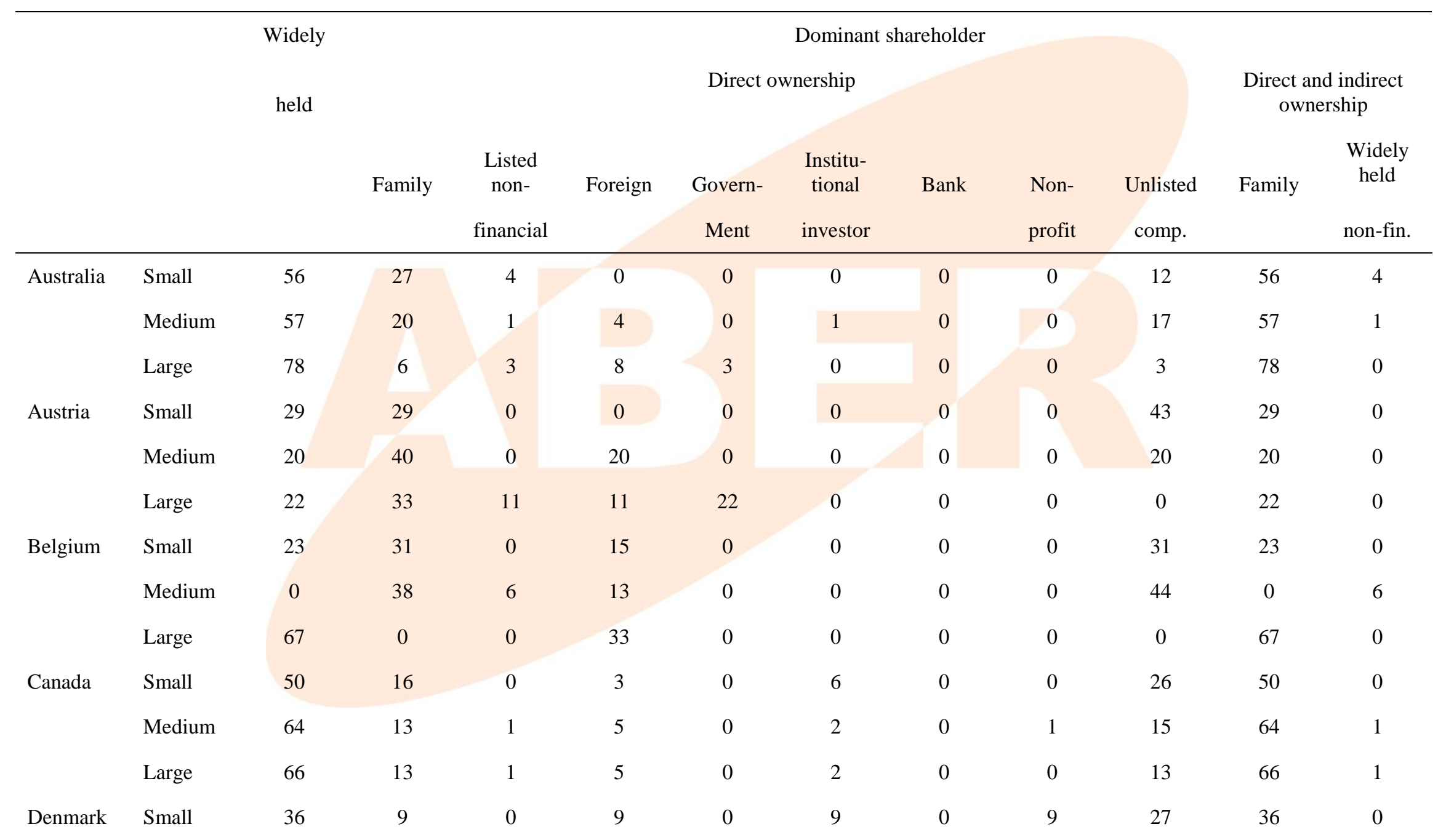


$6^{\text {th }}$ Global Conference on Business \& Economics

ISBN : 0-9742114-6-X

\begin{tabular}{|c|c|c|c|c|c|c|c|c|c|c|c|c|}
\hline & Medium & 22 & 11 & 6 & 11 & 0 & 0 & 0 & 22 & 28 & 22 & 0 \\
\hline & Large & 50 & 0 & 0 & 0 & 25 & 0 & 0 & 25 & 0 & 50 & 0 \\
\hline \multirow[t]{3}{*}{ Finland } & Small & 31 & 25 & 13 & 0 & 0 & 0 & 0 & 0 & 31 & 31 & 6 \\
\hline & Medium & 48 & 10 & 5 & 5 & 0 & 5 & 0 & 5 & 24 & 48 & 5 \\
\hline & Large & 33 & 33 & 0 & 0 & 33 & 0 & 0 & 0 & 0 & 33 & 0 \\
\hline \multirow[t]{3}{*}{ France } & Small & 6 & 43 & 0 & 1 & 0 & 0 & 0 & 0 & 49 & 6 & 0 \\
\hline & Medium & 13 & 41 & 1 & 6 & 0 & 0 & 0 & 0 & 39 & 13 & 0 \\
\hline & Large & 40 & 19 & 14 & 6 & 6 & 0 & 0 & 3 & 13 & 40 & 10 \\
\hline \multirow[t]{3}{*}{ Germany } & Small & 24 & 42 & 7 & 7 & 0 & 1 & 1 & 0 & 18 & 24 & 6 \\
\hline & Medium & 17 & 27 & 3 & 14 & 0 & 0 & 0 & 0 & 39 & 17 & 2 \\
\hline & Large & 34 & 10 & 14 & 8 & 5 & 2 & 0 & 2 & 25 & 34 & 7 \\
\hline Hong & Small & 8 & 42 & 8 & 14 & 1 & 1 & 0 & 0 & 27 & 8 & 2 \\
\hline \multirow[t]{2}{*}{ Kong } & Medium & 9 & 36 & 9 & 13 & 0 & 0 & 0 & 0 & 33 & 9 & 1 \\
\hline & Large & 14 & 25 & 7 & 21 & 7 & 0 & 0 & 0 & 25 & 14 & 0 \\
\hline \multirow[t]{3}{*}{ Ireland } & Small & 71 & 14 & 0 & 0 & 0 & 14 & 0 & 0 & 0 & 71 & 0 \\
\hline & Medium & 57 & 0 & 0 & 43 & 0 & 0 & 0 & 0 & 0 & 57 & 0 \\
\hline & Large & 33 & 0 & 33 & 0 & 11 & 0 & 0 & 0 & 22 & 33 & 11 \\
\hline \multirow[t]{3}{*}{ Israel } & Small & 41 & 12 & 18 & 0 & 0 & 0 & 0 & 0 & 29 & 41 & 6 \\
\hline & Medium & 27 & 14 & 32 & 0 & 0 & 5 & 0 & 0 & 23 & 27 & 14 \\
\hline & Large & 11 & 33 & 11 & 0 & 11 & 0 & 0 & 0 & 33 & 11 & 11 \\
\hline \multirow[t]{2}{*}{ Italy } & Small & 22 & 48 & 0 & 11 & 4 & 0 & 0 & 0 & 15 & 22 & 0 \\
\hline & Medium & 3 & 51 & 5 & 5 & 5 & 0 & 0 & 0 & 30 & 3 & 3 \\
\hline
\end{tabular}


$6^{\text {th }}$ Global Conference on Business \& Economics

ISBN : 0-9742114-6-X

\begin{tabular}{|c|c|c|c|c|c|c|c|c|c|c|c|c|}
\hline & Large & 8 & 25 & 13 & 4 & 17 & 0 & 0 & 0 & 33 & 8 & 4 \\
\hline \multirow[t]{3}{*}{ Japan } & Small & 53 & 15 & 17 & 0 & 0 & 1 & 1 & 0 & 13 & 53 & 17 \\
\hline & Medium & 60 & 6 & 22 & 0.5 & 0 & 0 & 0 & 0.2 & 11 & 60 & 20 \\
\hline & Large & 70 & 2 & 16 & 4 & 1 & 0 & 0 & 0 & 9 & 70 & 13 \\
\hline \multirow[t]{3}{*}{ Korea } & Small & 41 & 23 & 6 & 2 & 1 & 2 & 4 & 0 & 20 & 41 & 6 \\
\hline & Medium & 55 & 17 & 13 & 0 & 0 & 0 & 0 & 0 & 16 & 55 & 9 \\
\hline & Large & 63 & 0 & 19 & 6 & 6 & 0 & 0 & 0 & 6 & 63 & 19 \\
\hline Nether- & Small & 38 & 8 & 0 & 8 & 0 & 15 & 0 & 0 & 31 & 38 & 0 \\
\hline \multirow[t]{2}{*}{ lands } & Medium & 48 & 5 & 5 & 10 & 5 & 0 & 0 & 0 & 29 & 48 & 5 \\
\hline & Large & 71 & 0 & 0 & 12 & 6 & 0 & 0 & 0 & 12 & 71 & 0 \\
\hline New & Small & 50 & 20 & 0 & 0 & 0 & 0 & 0 & 0 & 30 & 50 & 0 \\
\hline \multirow[t]{2}{*}{ Zealand } & Medium & 27 & 33 & 0 & 20 & 0 & 0 & 0 & 0 & 20 & 27 & 0 \\
\hline & Large & 43 & 14 & 0 & 0 & 0 & 14 & 0 & 14 & 14 & 43 & 0 \\
\hline \multirow[t]{3}{*}{ Norway } & Small & 19 & 19 & 0 & 6 & 0 & 6 & 0 & 0 & 50 & 19 & 0 \\
\hline & Medium & 62 & 5 & 5 & 0 & 0 & 5 & 0 & 0 & 24 & 62 & 0 \\
\hline & Large & 0 & 0 & 25 & 0 & 13 & 0 & 0 & 0 & 63 & 0 & 13 \\
\hline \multirow[t]{3}{*}{ Portugal } & Small & 33 & 0 & 0 & 0 & 0 & 0 & 0 & 0 & 67 & 33 & 0 \\
\hline & Medium & 25 & 0 & 13 & 0 & 0 & 13 & 0 & 0 & 50 & 25 & 0 \\
\hline & Large & 22 & 11 & 0 & 11 & 44 & 0 & 0 & 0 & 11 & 22 & 0 \\
\hline Singa- & Small & 23 & 35 & 0 & 7 & 4 & 0 & 2 & 0 & 29 & 23 & 0 \\
\hline \multirow[t]{2}{*}{ Pore } & Medium & 10 & 43 & 3 & 10 & 5 & 0 & 8 & 0 & 23 & 10 & 3 \\
\hline & Large & 25 & 6 & 0 & 6 & 44 & 6 & 0 & 0 & 13 & 25 & 0 \\
\hline
\end{tabular}


$6^{\text {th }}$ Global Conference on Business \& Economics

ISBN : 0-9742114-6-X

\begin{tabular}{|c|c|c|c|c|c|c|c|c|c|c|c|c|}
\hline \multirow[t]{3}{*}{ Spain } & Small & 50 & 33 & 0 & 0 & 0 & 0 & 17 & 0 & 0 & 50 & 0 \\
\hline & Medium & 31 & 46 & 0 & 4 & 0 & 0 & 0 & 0 & 19 & 31 & 0 \\
\hline & Large & 40 & 15 & 15 & 5 & 5 & 0 & 10 & 0 & 10 & 40 & 15 \\
\hline \multirow[t]{3}{*}{ Sweden } & Small & 38 & 38 & 6 & 0 & 0 & 0 & 0 & 0 & 19 & 38 & 3 \\
\hline & Medium & 32 & 44 & 0 & 4 & 0 & 0 & 0 & 0 & 20 & 32 & 0 \\
\hline & Large & 20 & 7 & 27 & 7 & 7 & 0 & 0 & 7 & 27 & 20 & 7 \\
\hline Switzer- & Small & 58 & 25 & 0 & 8 & 0 & 0 & 0 & 0 & 8 & 58 & 0 \\
\hline \multirow[t]{2}{*}{ land } & Medium & 36 & 32 & 4 & 8 & 0 & 8 & 4 & 0 & 8 & 36 & 4 \\
\hline & Large & 48 & 16 & 8 & 4 & 8 & 0 & 0 & 4 & 12 & 48 & 8 \\
\hline United & Small & 54 & 28 & 0 & 3 & 0 & 5 & 0 & 0 & 10 & 54 & 0 \\
\hline \multirow[t]{2}{*}{ Kingdom } & Medium & 58 & 25 & 8 & 0 & 0 & 4 & 0 & 0 & 4 & 58 & 8 \\
\hline & Large & 86 & 6 & 1 & 1 & 0 & 1 & 0 & 0 & 4 & 86 & 1 \\
\hline United & Small & 56 & 30 & 1 & 0 & 0 & 3 & 0 & 0 & 11 & 56 & 1 \\
\hline \multirow[t]{2}{*}{ States } & Medium & 66 & 16 & 1 & 1 & 0 & 4 & 0 & 0.5 & 11 & 66 & 1 \\
\hline & Large & 87 & 6 & 1 & 2 & 0 & 1 & 0 & 0 & 4 & 87 & 1 \\
\hline \multirow[t]{3}{*}{ Sample } & Small & 39 & 28 & 5 & 4 & 0.5 & 2 & 1 & 0.1 & 21 & 39 & 4 \\
\hline & Medium & 48 & 19 & 6 & 5 & 0.4 & 2 & 0.4 & 1 & 17 & 48 & 5 \\
\hline & Large & 63 & 9 & 7 & 4 & 4 & 1 & 0.2 & 1 & 11 & 63 & 4 \\
\hline
\end{tabular}


Table 6

Ownership patterns, firm size and industry affiliation: estimations for widely held firms

\begin{tabular}{|c|c|c|c|c|c|c|c|}
\hline & Size & Mining & $\begin{array}{l}\text { Manufac- } \\
\text { turing }\end{array}$ & Utilities & Trade & Services & $\begin{array}{c}\text { Agricul- } \\
\text { ture }\end{array}$ \\
\hline Australia & $0.130^{*}$ & -0.239 & -0.409 & -0.626 & -0.397 & -0.282 & \\
\hline Austria & $0.730^{*}$ & NI & $-6.143^{s}$ & $-7.260^{\mathrm{s}}$ & NI & $-3.172^{\mathrm{cm}}$ & \\
\hline Belgium & 0.059 & -1.910 & $-3.850^{\mathrm{st}}$ & NI & $-0.929^{\mathrm{m}}$ & $-0.970^{\mathrm{m}}$ & \\
\hline Canada & $0.130^{* *}$ & $0.167^{\text {tu }}$ & $-0.070^{\mathrm{t}}$ & $-0.484^{\mathrm{c}}$ & $-0.671^{\mathrm{cm}}$ & -0.298 & \\
\hline Denmark & 0.008 & NI & $-1.434^{\mathrm{s}}$ & -0.744 & -0.733 & $-0.040^{\mathrm{m}}$ & \\
\hline Finland & 0.055 & NI & $-0.654^{\mathrm{s}}$ & -0.054 & 0.603 & -0.870 & \\
\hline France & $0.439^{* * *}$ & -4.505 & -4.334 & -4.443 & $-4.620^{\mathrm{s}}$ & $-3.718^{\mathrm{mt}}$ & \\
\hline Germany & $0.180^{* *}$ & -2.131 & -2.069 & -2.547 & -2.483 & -2.078 & \\
\hline Hong Kong & $0.337^{* * *}$ & -4.692 & $-3.756^{\mathrm{u}}$ & $-5.387^{\mathrm{m}}$ & -4.108 & -4.150 & \\
\hline Ireland & 0.209 & 0.774 & -0.311 & NI & 0.781 & -0.882 & \\
\hline Israel & 0.107 & No & $-1.251^{\mathrm{s}}$ & No & $-2.795^{\mathrm{s}}$ & $0.040^{\mathrm{mt}}$ & \\
\hline Italy & -0.224 & No & -0.504 & -1.554 & No & -0.817 & \\
\hline Japan & $0.142^{* * *}$ & $-0.363^{\mathrm{s}}$ & $0.044^{\mathrm{st}}$ & -0.306 & $-0.682^{\mathrm{m}}$ & $-0.981^{\mathrm{cm}}$ & \\
\hline Korea & $0.160^{*}$ & -0.578 & -0.977 & -0.966 & -0.671 & -0.598 & \\
\hline Netherlands & $0.343^{* *}$ & $-0.889^{t}$ & $-1.382^{t}$ & -2.355 & $-2.636^{\mathrm{cm}}$ & -1.700 & \\
\hline New Zealand & 0.280 & NI & -1.926 & -2.528 & -2.481 & -1.922 & \\
\hline Norway & -0.104 & $0.810^{\mathrm{u}}$ & 0.242 & $-0.656^{c}$ & 0.489 & 0.023 & \\
\hline Portugal & -1.206 & 4.693 & No & NI & NI & 5.200 & \\
\hline Singapore & 0.027 & -2.412 & -1.516 & -1.533 & -2.181 & -1.469 & \\
\hline Spain & 0.107 & $-2.181^{\mathrm{m}}$ & $-0.446^{\mathrm{cu}}$ & $-1.671^{\mathrm{m}}$ & -0.617 & -1.397 & \\
\hline Sweden & -0.078 & -0.533 & $-0.470^{\mathrm{t}}$ & $-1.731^{\mathrm{t}}$ & $0.539^{\mathrm{mu}}$ & -0.051 & \\
\hline Switzerland & 0.134 & NI & $-0.972^{\mathrm{u}}$ & $-2.439^{m}$ & -1.820 & -1.134 & \\
\hline United & $0.381^{* * *}$ & $-0.774^{\text {tu }}$ & $-1.039^{\mathrm{tu}}$ & $-1.702^{\mathrm{cms}}$ & $-1.518^{\mathrm{cm}}$ & $-1.194^{\mathrm{u}}$ & \\
\hline Kingdom & & & & & & & \\
\hline United States & $0.316^{* * *}$ & -0.668 & $-0.840^{\mathrm{s}}$ & $-0.645^{\mathrm{s}}$ & -0.991 & $-1.109^{\mathrm{mu}}$ & \\
\hline Sample & $0.139^{* * *}$ & $-0.192^{\mathrm{u}}$ & $-0.307^{\mathrm{su}}$ & $-0.749^{\mathrm{cmst}}$ & $-0.361^{\text {su }}$ & $-0.046^{\mathrm{amtu}}$ & $0.570^{\mathrm{s}}$ \\
\hline
\end{tabular}

'NI' indicates that there are less than five firms in this industry in this country. The firms in this industry are thus not included in the estimation.

'No' indicates that there are no firms in this industry in this country that belong to this ownership category. The firms in this industry are thus not included in the estimation.

$*, * *, * * *$ indicate that the coefficient is significantly different from zero at 10,5 and 1 percent level. The significance levels are not reported for industry dummies since they are irrelevant for the purposes of the analysis

The superscript letters indicate that the coefficient of this industry dummy is different from the coefficient of the industry dummy indicated by the letter at 10 percent level.

$a-$ agriculture

$\mathrm{c}-$ mining and construction

$\mathrm{m}$ - manufacturing

$$
\begin{aligned}
& \mathrm{s} \text { - services } \\
& \mathrm{t} \text { - trade sector } \\
& \mathrm{u} \text { - utilities }
\end{aligned}
$$


Table 7

Ownership patterns, firm size and industry affiliation: estimations for directly family controlled firms

\begin{tabular}{|c|c|c|c|c|c|c|c|}
\hline & Size & Mining & $\begin{array}{l}\text { Manufac- } \\
\text { turing }\end{array}$ & Utilities & Trade & Services & $\begin{array}{l}\text { Agricul- } \\
\text { ture }\end{array}$ \\
\hline Australia & $-0.345^{* * * *}$ & $-0.411^{\mathrm{mst}}$ & $0.530^{c}$ & 0.112 & $0.389^{c}$ & $0.719^{\mathrm{c}}$ & \\
\hline Austria & $-0.819^{* *}$ & NI & 3.756 & 3.186 & NI & No & \\
\hline Belgium & 0.129 & -2.278 & -1.356 & NI & -2.056 & -0.605 & \\
\hline Canada & -0.101 & $-1.934^{\mathrm{mst}}$ & $-1.164^{\mathrm{c}}$ & -1.344 & $-0.772^{c}$ & $-0.761^{\mathrm{c}}$ & \\
\hline Denmark & -0.268 & NI & -0.494 & -0.807 & -1.112 & No & \\
\hline Finland & -0.200 & NI & -0.838 & No & -0.692 & -0.606 & \\
\hline France & $-0.286^{* * *}$ & 0.267 & $0.734^{\mathrm{t}}$ & 0.722 & $1.371^{\mathrm{m}}$ & 1.037 & \\
\hline Germany & $-0.359^{* * * *}$ & $1.489^{\mathrm{u}}$ & $1.031^{\mathrm{u}}$ & $-0.604^{\mathrm{cmst}}$ & $1.204^{\mathrm{u}}$ & $1.060^{\mathrm{u}}$ & \\
\hline Hong Kong & $-0.141^{*}$ & -0.160 & $0.299^{\mathrm{u}}$ & $-0.546^{\mathrm{m}}$ & 0.086 & -0.027 & \\
\hline Ireland & -0.131 & No & -0.692 & NI & No & -0.565 & \\
\hline Israel & -0.345 & 0.311 & 0.173 & No & $1.040^{\mathrm{s}}$ & $-1.423^{\mathrm{t}}$ & \\
\hline Italy & -0.130 & 0.459 & $0.704^{\mathrm{u}}$ & $-0.906^{\mathrm{mst}}$ & $1.277^{\mathrm{u}}$ & $0.973^{\mathrm{u}}$ & \\
\hline Japan & $-0.500^{* * *}$ & $-0.461^{\mathrm{s}}$ & $-0.599^{\mathrm{st}}$ & 0.172 & $0.387^{\mathrm{ms}}$ & $1.068^{\mathrm{cmt}}$ & \\
\hline Korea & $-0.508^{* * *}$ & 1.189 & 0.903 & $-0.708^{t}$ & $1.463^{\mathrm{su}}$ & $-0.551^{t}$ & \\
\hline Netherlands & -0.476 & No & -0.054 & No & -0.012 & -0.707 & \\
\hline New Zealand & -0.400 & NI & 0.890 & 0.383 & 1.561 & 1.456 & \\
\hline Norway & 0.078 & -2.520 & -3.055 & -2.279 & No & -2.076 & \\
\hline Portugal & All small & No & No & NI & NI & & \\
\hline Singapore & $-0.383^{* * *}$ & 1.378 & $1.576^{\mathrm{su}}$ & $0.605^{\mathrm{m}}$ & 1.510 & $0.961^{\mathrm{m}}$ & \\
\hline Spain & -0.262 & -0.384 & -0.117 & -0.784 & 0.797 & 1.001 & \\
\hline Sweden & $-0.316^{* *}$ & 0.796 & 1.021 & No & 1.045 & 0.419 & \\
\hline Switzerland & $-0.298^{* *}$ & NI & 1.023 & -0.128 & 0.723 & 0.542 & \\
\hline United & $-0.502^{* * *}$ & $0.672^{t}$ & $0.664^{\text {tu }}$ & $1.421^{\mathrm{m}}$ & $1.442^{\mathrm{cms}}$ & $0.937^{t}$ & \\
\hline Kingdom & & & & & & & \\
\hline United States & $-0.355^{* * *}$ & 0.241 & $0.227^{\mathrm{s}}$ & 0.168 & 0.600 & $0.576^{\mathrm{m}}$ & \\
\hline Sample & $-0.248^{* * *}$ & $-1.699^{\mathrm{amst}}$ & $-1.098^{\mathrm{cu}}$ & $-1.892^{\mathrm{amst}}$ & $-1.025^{\mathrm{cu}}$ & $-1.159^{\text {cu }}$ & $-1.133^{\mathrm{cu}}$ \\
\hline
\end{tabular}

'NI' indicates that there are less than five firms in this industry in this country. The firms in this industry are thus not included in the estimation.

'No' indicates that there are no firms in this industry in this country that belong to this ownership category. The firms in this industry are thus not included in the estimation.

$*, * *, * * *$ indicate that the coefficient is significantly different from zero at 10,5 and 1 percent level. The significance levels are not reported for industry dummies since they are irrelevant for the purposes of the analysis

The superscript letters indicate that the coefficient of this industry dummy is different from the coefficient of the industry dummy indicated by the letter at 10 percent level.

a- agriculture

$\mathrm{c}-$ mining and construction

$\mathrm{m}$ - manufacturing $\mathrm{s}$ - services

$\mathrm{t}$ - trade sector

u - utilities 
Table 8

Ownership patterns, firm size and industry a1ffiliation: estimations for firms controlled by unlisted companies

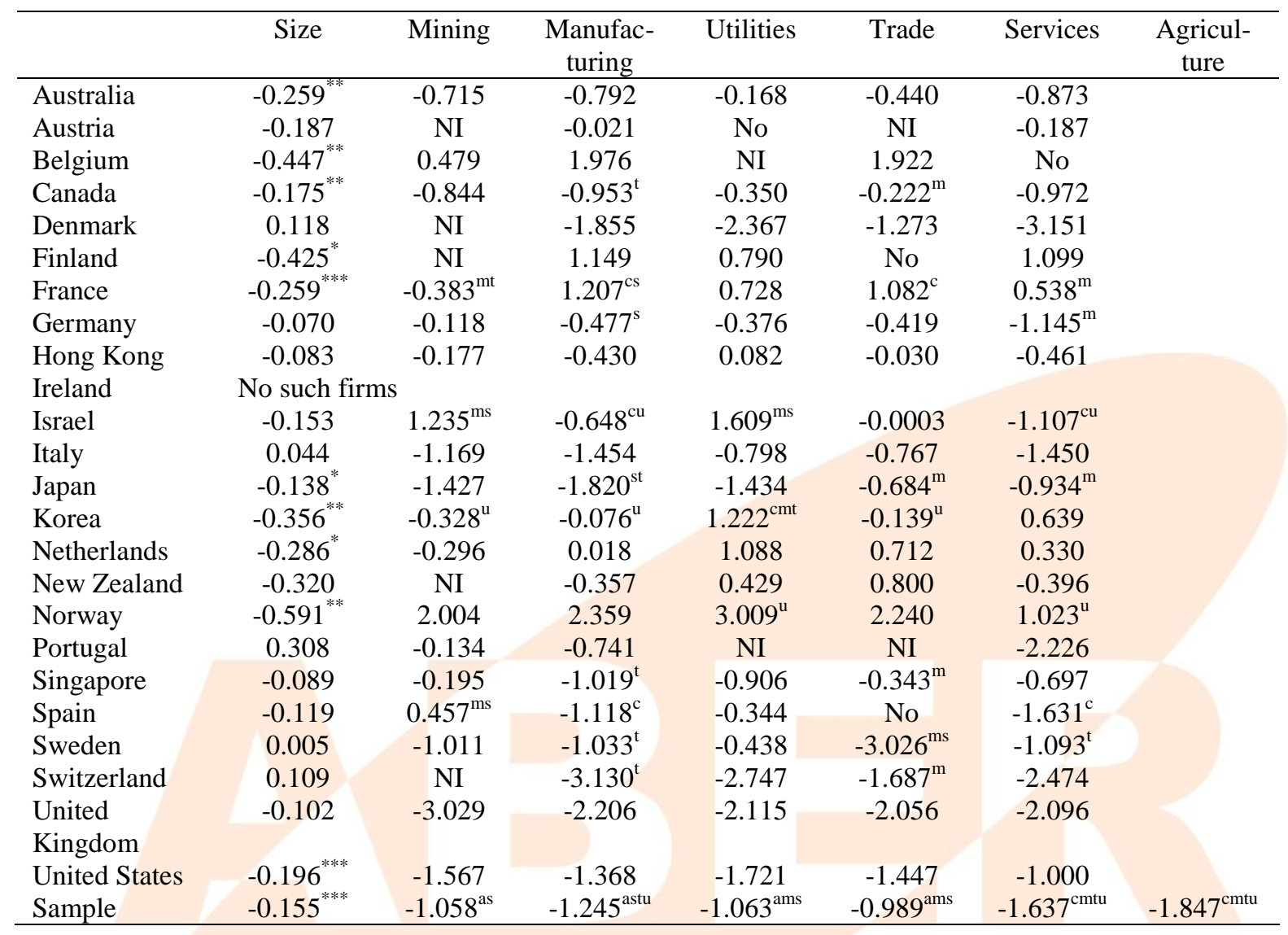

'NI' indicates that there are less than five firms in this industry in this country. The firms in this industry are thus not included in the estimation.

'No' indicates that there are no firms in this industry in this country that belong to this ownership category. The firms in this industry are thus not included in the estimation.

$*, * *, * * *$ indicate that the coefficient is significantly different from zero at 10,5 and 1 percent level. The significance levels are not reported for industry dummies since they are irrelevant for the purposes of the analysis

The superscript letters indicate that the coefficient of this industry dummy is different from the coefficient of the industry dummy indicated by the letter at 10 percent level.

a - agriculture

$\mathrm{c}-$ mining and construction

$\mathrm{s}$ - services

$\mathrm{m}$ - manufacturing

$\mathrm{t}$ - trade sector

u - utilities 
Table 9

Ownership patterns, firm size and industry affiliation

\begin{tabular}{|c|c|c|c|c|c|c|c|}
\hline $\begin{array}{l}\text { Dominant } \\
\text { shareholder }\end{array}$ & Size & Mining & $\begin{array}{l}\text { Manufac- } \\
\text { turing }\end{array}$ & Utilities & Trade & Services & Agricul-ture \\
\hline Listed & $0.189^{* * * *}$ & $-2.470^{\mathrm{amu}}$ & $-2.827^{\text {astu }}$ & $-2.046^{\mathrm{acmst}}$ & $-2.424^{\mathrm{amu}}$ & $-2.436^{\mathrm{amu}}$ & $-1.326^{\mathrm{cmstu}}$ \\
\hline Foreign & 0.034 & $-4.100^{t}$ & $-4.408^{\mathrm{u}}$ & $-4.042^{\mathrm{mt}}$ & $-4.677^{\mathrm{csu}}$ & $-4.196^{\mathrm{tu}}$ & -4.211 \\
\hline Government & $0.521^{* * *}$ & $-10.304^{\text {tu }}$ & $-10.273^{\text {tu }}$ & $-8.386^{\mathrm{acmst}}$ & $-13.415^{\text {acmsu }}$ & $-10.465^{\text {tu }}$ & $-10.617^{\text {tu }}$ \\
\hline $\begin{array}{l}\text { Institutional } \\
\text { investor } \\
\text { Direct and } \\
\text { indirect } \\
\text { ownership }\end{array}$ & $-0.300^{* * *}$ & $-6.084^{\mathrm{m}}$ & $-4.808^{\text {cstu }}$ & $-6.683^{\mathrm{ms}}$ & $-6.084^{\mathrm{m}}$ & $-5.462^{\mathrm{mu}}$ & No \\
\hline $\begin{array}{l}\text { Widely held } \\
\text { firms as } \\
\text { dominant } \\
\text { shareholders }\end{array}$ & $0.180^{* * *}$ & -2.410 & $-2.773^{u}$ & $-2.003^{\mathrm{mst}}$ & $-2.817^{\mathrm{u}}$ & $-2.465^{\mathrm{u}}$ & No \\
\hline
\end{tabular}

'No' indicates that there are no firms in this industry that belong to this ownership category. The firms in this industry are thus not included in the estimation.

$*, * *, * * *$ indicate that the coefficient is significantly different from zero at 10,5 and 1 percent level. The significance levels are not reported for industry dummies since they are irrelevant for the purposes of the analysis

The superscript letters indicate that the coefficient of this industry dummy is different from the coefficient of the industry dummy indicated by the letter at 10 percent level.

a- agriculture

$\mathrm{c}-$ mining and construction

$\mathrm{m}$ - manufacturing

$\mathrm{s}-$ services

$\mathrm{t}$ - trade sector

$\mathrm{u}$ - utilities 
Table 10

Ownership patterns, firm size and industry affiliation: estimations for firms directly or indirectly controlled by families

\begin{tabular}{|c|c|c|c|c|c|c|c|}
\hline & Size & Mining & $\begin{array}{l}\text { Manufac- } \\
\text { turing }\end{array}$ & Utilities & Trade & Services & $\begin{array}{l}\text { Agricul- } \\
\text { ture }\end{array}$ \\
\hline Australia & $-0.345^{* * *}$ & $0.546^{\mathrm{ms}}$ & $1.089^{\mathrm{c}}$ & 1.135 & 1.159 & $1.222^{\mathrm{c}}$ & \\
\hline Austria & $-0.928^{* *}$ & NI & $6.300^{\mathrm{su}}$ & $3.774^{\mathrm{m}}$ & NI & $3.377^{\mathrm{m}}$ & \\
\hline Belgium & -0.196 & $0.278^{\mathrm{m}}$ & $2.151^{\mathrm{c}}$ & NI & 1.738 & 1.621 & \\
\hline Canada & $-0.161^{* *}$ & $-0.386^{\text {stu }}$ & $-0.021^{t}$ & $0.308^{c}$ & $0.667^{\mathrm{cm}}$ & $0.221^{\mathrm{c}}$ & \\
\hline Denmark & -0.0003 & NI & $-0.574^{\mathrm{s}}$ & -1.097 & $0.001^{\mathrm{s}}$ & $-2.564^{\mathrm{mt}}$ & \\
\hline Finland & $-0.403^{* *}$ & NI & 1.672 & 0.658 & 0.362 & 1.784 & \\
\hline France & $-0.553^{* * *}$ & $2.527^{\mathrm{mstu}}$ & $4.418^{\text {ct }}$ & $4.006^{\mathrm{ct}}$ & $5.220^{\mathrm{cmsu}}$ & $3.893^{\mathrm{ct}}$ & \\
\hline Germany & $-0.296^{* * *}$ & 2.814 & $2.120^{\text {su }}$ & $1.342^{\mathrm{mt}}$ & $2.306^{\mathrm{u}}$ & $1.615^{\mathrm{m}}$ & \\
\hline Hong Kong & $-0.239^{* * *}$ & 2.143 & 2.201 & 2.589 & 2.422 & 2.414 & \\
\hline Ireland & -0.131 & No & -0.692 & NI & No & -0.564 & \\
\hline Israel & -0.204 & All & $1.020^{\mathrm{t}}$ & $1.908^{\mathrm{s}}$ & $3.341^{\mathrm{ms}}$ & $0.219^{\text {tu }}$ & \\
\hline Italy & -0.094 & 1.465 & $1.496^{\mathrm{u}}$ & $0.778^{\mathrm{ms}}$ & All & $1.902^{\mathrm{u}}$ & \\
\hline Japan & $-0.289^{* * *}$ & $-0.086^{\text {st }}$ & $-0.502^{\mathrm{st}}$ & $0.072^{\mathrm{s}}$ & $0.706^{\mathrm{cm}}$ & $0.958^{\mathrm{cmu}}$ & \\
\hline Korea & $-0.409^{* * *}$ & 1.397 & 1.405 & 1.671 & 1.630 & 0.890 & \\
\hline Netherlands & $-0.359^{* *}$ & 0.118 & 0.850 & 1.573 & 1.467 & 0.937 & \\
\hline New Zealand & $-0.529^{* *}$ & NI & $2.132^{\mathrm{t}}$ & 2.348 & $3.548^{\mathrm{m}}$ & 2.632 & \\
\hline Norway & $-0.446^{* *}$ & 2.279 & $1.957^{\mathrm{u}}$ & $3.052^{\mathrm{ms}}$ & 2.089 & $1.278^{\mathrm{u}}$ & \\
\hline Portugal & 0.896 & -3.182 & -2.375 & NI & NI & -4.437 & \\
\hline Singapore & $-0.413^{* * *}$ & 3.215 & 2.539 & $1.796^{\mathrm{t}}$ & $3.084^{\mathrm{su}}$ & $2.174^{t}$ & \\
\hline Spain & -0.256 & $2.302^{\mathrm{m}}$ & $0.801^{\mathrm{c}}$ & 1.066 & 0.766 & 1.674 & \\
\hline Sweden & $-0.204^{*}$ & 1.361 & $1.605^{\mathrm{t}}$ & 1.659 & $0.655^{\mathrm{m}}$ & 1.117 & \\
\hline Switzerland & $-0.191^{*}$ & NI & 0.742 & $0.056^{\mathrm{t}}$ & $1.427^{\mathrm{u}}$ & 0.612 & \\
\hline United & $-0.403^{* * *}$ & $0.397^{\text {tu }}$ & $0.658^{\text {tu }}$ & $1.257^{\mathrm{cm}}$ & $1.345^{\mathrm{cms}}$ & $0.892^{t}$ & \\
\hline Kingdom & & & & & & & \\
\hline United States & $-0.330^{* * *}$ & 0.561 & $0.629^{s}$ & $0.449^{\mathrm{s}}$ & 0.879 & $1.051^{\mathrm{mu}}$ & \\
\hline Sample & $-0.271^{* * *}$ & $-0.198^{\mathrm{mt}}$ & $0.026^{\text {cstu }}$ & $-0.245^{\mathrm{mt}}$ & $0.386^{\text {cmsu }}$ & $-0.292^{\mathrm{mt}}$ & 0.085 \\
\hline
\end{tabular}

'NI' indicates that there are less than five firms in this industry in this country. The firms in this industry are thus not included in the estimation.

'No' indicates that there are no firms in this industry in this country that belong to this ownership category. The firms in this industry are thus not included in the estimation.

$*, * *, * * *$ indicate that the coefficient is significantly different from zero at 10,5 and 1 percent level. The significance levels are not reported for industry dummies since they are irrelevant for the purposes of the analysis

The superscript letters indicate that the coefficient of this industry dummy is different from the coefficient of the industry dummy indicated by the letter at 10 percent level.
a - agriculture
$\mathrm{c}-$ mining and construction
$\mathrm{s}$ - services
$\mathrm{m}$ - manufacturing
$\mathrm{t}-$ trade sector
u - utilities

Table 11

Ownership patterns, firm size and industry affiliation: manufacturing industries

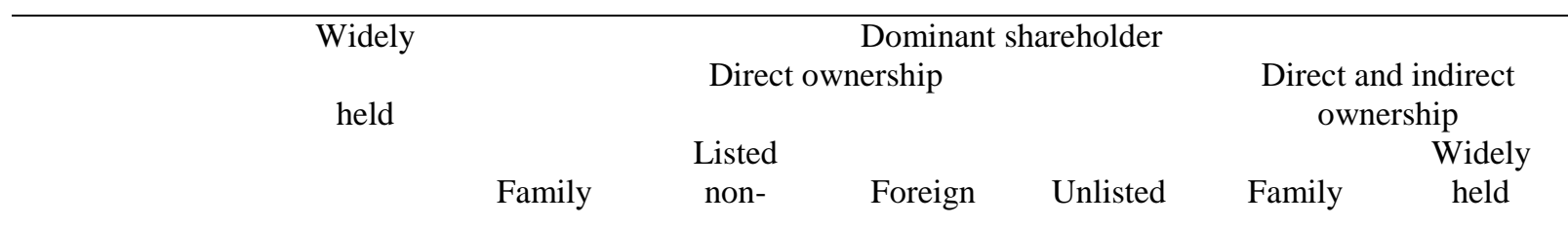


Financial

\begin{tabular}{|c|c|c|c|c|c|c|c|}
\hline & & & & & & & \\
\hline Size & $0.155^{* * * *}$ & $-0.246^{* * * *}$ & $0.201^{* * *}$ & 0.011 & $-0.155^{* * * *}$ & $-0.266^{* * * *}$ & $0.188^{* * *}$ \\
\hline Food & -0.583 & -1.174 & $-4.382^{\mathrm{a}}$ & -4.329 & $-0.739^{\mathrm{b}}$ & $0.343^{\mathrm{b}}$ & $-4.308^{\mathrm{a}}$ \\
\hline Textiles & -0.569 & $-0.420^{b}$ & -2.640 & $-6.392^{\mathrm{a}}$ & -1.427 & $0.662^{b}$ & No \\
\hline Clothing & -0.468 & $-0.861^{a}$ & $-4.915^{a}$ & -4.760 & -1.078 & $0.392^{\mathrm{b}}$ & No \\
\hline Wood & $-0.848^{\mathrm{a}}$ & -1.046 & $-2.024^{b}$ & $-2.794^{\mathrm{b}}$ & -1.541 & 0.110 & No \\
\hline Paper & $-0.904^{a}$ & -1.293 & $-4.031^{a}$ & $-3.744^{b}$ & $-0.950^{b}$ & -0.023 & -3.116 \\
\hline Printing & $-1.258^{a}$ & $-0.343^{b}$ & -3.751 & $-3.689^{b}$ & $-1.030^{b}$ & $0.756^{\mathrm{b}}$ & -3.184 \\
\hline $\begin{array}{l}\text { Chemicals } \\
\text { excluding drugs }\end{array}$ & $-0.236^{\mathrm{b}}$ & $-1.748^{\mathrm{a}}$ & $-2.413^{b}$ & -4.135 & -1.499 & $-0.559^{\mathrm{a}}$ & -2.269 \\
\hline Drugs & -0.258 & -1.081 & $-3.895^{a}$ & -4.122 & $-0.823^{b}$ & 0.288 & $-3.900^{a}$ \\
\hline Petroleum & $-1.281^{a}$ & $-2.126^{\mathrm{a}}$ & $-4.226^{\mathrm{a}}$ & $-2.789^{b}$ & $-2.544^{\mathrm{a}}$ & $-1.449^{\mathrm{a}}$ & -3.806 \\
\hline Rubber \& Plastic & $-0.761^{a}$ & -1.108 & $-1.896^{b}$ & -4.296 & $-0.828^{b}$ & $0.350^{\mathrm{b}}$ & $-1.548^{\mathrm{b}}$ \\
\hline Leather & -0.347 & $-0.677^{b}$ & $-2.008^{b}$ & -4.172 & $-2.018^{\mathrm{a}}$ & -0.019 & $-1.741^{b}$ \\
\hline Non-Metallic & $-0.136^{b}$ & -1.149 & $-2.180^{b}$ & -4.755 & $-1.631^{a}$ & -0.037 & -3.320 \\
\hline \multicolumn{8}{|l|}{ Products } \\
\hline Basic Metal & -0.570 & -1.385 & $-2.386^{b}$ & $-5.134^{\mathrm{a}}$ & -1.172 & -0.172 & $-1.965^{b}$ \\
\hline Metal Products & -0.308 & -0.884 & -3.404 & -4.414 & -1.175 & 0.252 & -3.546 \\
\hline Machinery \& & -0.470 & -0.980 & $-2.351^{b}$ & -4.106 & -1.374 & 0.042 & $-1.965^{b}$ \\
\hline \multicolumn{8}{|l|}{ Equipment, nec } \\
\hline Computing & $0.243^{\mathrm{b}}$ & $-0.646^{b}$ & $-4.234^{\mathrm{a}}$ & $-4.861^{a}$ & $-1.850^{a}$ & -0.186 & $-3.916^{\mathrm{a}}$ \\
\hline Electrical & $-0.054^{b}$ & $-1.399^{\mathrm{a}}$ & $-3.935^{a}$ & $-4.818^{a}$ & -1.099 & -0.101 & $-4.056^{\mathrm{a}}$ \\
\hline \multicolumn{8}{|l|}{ Machinery } \\
\hline Communication & $0.082^{b}$ & $-1.426^{a}$ & -3.534 & $-4.987^{\mathrm{a}}$ & -1.163 & $-0.267^{a}$ & -3.197 \\
\hline \multicolumn{8}{|l|}{ Equipment } \\
\hline Aircraft & -0.499 & $-2.273^{\mathrm{a}}$ & -2.570 & $-2.374^{\mathrm{b}}$ & -1.602 & $-1.083^{\mathrm{a}}$ & -3.683 \\
\hline Transport & $-0.688^{a}$ & $-0.809^{b}$ & -2.512 & -4.516 & $-2.081^{a}$ & $-0.310^{a}$ & -2.520 \\
\hline \multicolumn{8}{|l|}{ Equipment } \\
\hline Instruments & $0.038^{\mathrm{b}}$ & -1.120 & -2.585 & -4.733 & $-1.930^{\mathrm{a}}$ & $-0.439^{\mathrm{a}}$ & -2.264 \\
\hline Other & -0.324 & -1.177 & -2.866 & -4.632 & $-0.934^{b}$ & $0.301^{\mathrm{b}}$ & -3.053 \\
\hline Manufacturing & & & & & & & \\
\hline
\end{tabular}

Superscript ' $a$ ' indicates that the industry belongs to the group of industries with smallest coefficients of their dummies, which all differ significantly from the coefficients of the group with the largest coefficients.

Superscript ' $b$ ' indicates that the industry belongs to the group of industries with largest coefficients of their dummies, which all differ significantly from the coefficients of the group with the snallest coefficients. 
Table 12

Control of publicly held firms: Comparison with other studies percentages of firms in a country

\begin{tabular}{|c|c|c|c|c|c|c|}
\hline & $\begin{array}{l}\text { Widely } \\
\text { held }\end{array}$ & $\begin{array}{l}\text { Widely } \\
\text { held } \\
\text { Faccio and } \\
\text { Lang }\end{array}$ & $\begin{array}{l}\text { Widely } \\
\text { held } \\
\text { Claessens } \\
\text { et al. }\end{array}$ & Family & $\begin{array}{c}\text { Family } \\
\text { Faccio and } \\
\text { Lang }\end{array}$ & $\begin{array}{c}\text { Family } \\
\text { Claessens et } \\
\text { al. }\end{array}$ \\
\hline Australia & 57 & & & 33 & & \\
\hline Austria & 21 & 12 & & 53 & 59 & \\
\hline Belgium & 14 & 9 & & 67 & 64 & \\
\hline Canada & 65 & & & 29 & & \\
\hline Denmark & 31 & & & 30 & & \\
\hline Finland & 45 & 32 & & 34 & 44 & \\
\hline France & 18 & 12 & & 71 & 71 & \\
\hline Germany & 25 & 10 & & 57 & 69 & \\
\hline Hong Kong & 9 & & 7 & 74 & & 67 \\
\hline Ireland & 74 & 62 & & 11 & 27 & \\
\hline Israel & 34 & & & 54 & & \\
\hline Italy & 11 & 9 & & 70 & 72 & \\
\hline Japan & 61 & & 80 & 20 & & 10 \\
\hline Korea & 48 & & 43 & 35 & & 48 \\
\hline Netherlands & 60 & & & 24 & & \\
\hline New Zealand & 34 & & & 44 & & \\
\hline Norway & 38 & 33 & & 45 & 44 & \\
\hline Portugal & 13 & 23 & & 78 & 55 & \\
\hline Singapore & 18 & & 5 & 62 & & 55 \\
\hline Spain & 43 & 26 & & 37 & 62 & \\
\hline Sweden & 34 & 37 & & 55 & 47 & \\
\hline Switzerland & 41 & 26 & & 39 & 56 & \\
\hline United Kingdom & 70 & 64 & & 22 & 25 & \\
\hline United States & 72 & & & 24 & & \\
\hline
\end{tabular}

All figures in the table present the percentage of firms controlled by different controlling owners at the $20 \%$ threshold. The figures from the present study and those from Faccio and Lang (2002) refer to non-financial firms (their Table 4), whereas the data from Claessens et al. (2000), Table 6 refer to all firms: financial and non-financial. 
Table 13

Direct and indirect control of publicly held firms: numbers of firms among the 20 largest firms

\begin{tabular}{|c|c|c|c|c|c|c|c|}
\hline & \multirow{2}{*}{$\begin{array}{c}\text { Widely } \\
\text { held }\end{array}$} & \multicolumn{6}{|c|}{ Dominant shareholder } \\
\hline & & Family & $\begin{array}{c}\text { Widely held } \\
\text { non- } \\
\text { financial }\end{array}$ & Foreign & $\begin{array}{c}\text { Govern- } \\
\text { ment }\end{array}$ & $\begin{array}{c}\text { Institutional } \\
\text { investor } \\
\text { or bank }\end{array}$ & Non-profit \\
\hline Australia & 15 & 2 & 0 & 2 & 1 & 0 & 0 \\
\hline Austria & 5 & 7 & 0 & 2 & 6 & 0 & 0 \\
\hline Belgium & 3 & 11 & 1 & 2 & 2 & 0 & 1 \\
\hline Canada & 14 & 3 & 0 & 3 & 0 & 0 & 0 \\
\hline Denmark & 6 & 5 & 1 & 2 & 1 & 1 & 4 \\
\hline Finland & 11 & 3 & 1 & 0 & 4 & 0 & 1 \\
\hline France & 13 & 3 & 2 & 0 & 2 & 0 & 0 \\
\hline Germany & 14 & 1 & 1 & 1 & 3 & 0 & 0 \\
\hline Hong Kong & 3 & 12 & 0 & 3 & 2 & 0 & 0 \\
\hline Ireland & 15 & 2 & 1 & 2 & 0 & 0 & 0 \\
\hline Israel & 4 & 12 & 2 & 1 & 1 & 0 & 0 \\
\hline Italy & 2 & 10 & 1 & 1 & 6 & 0 & 0 \\
\hline Japan & 17 & 0 & 1 & 0 & 2 & 0 & 0 \\
\hline Korea & 10 & 1 & 5 & 1 & 3 & 0 & 0 \\
\hline Netherlands & 13 & 4 & 0 & 2 & 1 & 0 & 0 \\
\hline New Zealand & 8 & 5 & 0 & 5 & 2 & 0 & 0 \\
\hline Norway & 5 & 8 & 0 & 0 & 5 & 1 & 1 \\
\hline Portugal & 2 & 17 & 1 & 0 & 0 & 0 & 0 \\
\hline Singapore & 5 & 4 & 0 & 1 & 8 & 2 & 0 \\
\hline Spain & 8 & 5 & 3 & 1 & 1 & 2 & 0 \\
\hline Sweden & 6 & 7 & 0 & 3 & 1 & 2 & 1 \\
\hline Switzerland & 10 & 6 & 1 & 2 & 1 & 0 & 0 \\
\hline United Kingdom & 18 & 2 & 0 & 0 & 0 & 0 & 0 \\
\hline United States & 19 & 1 & 0 & 0 & 0 & 0 & 0 \\
\hline
\end{tabular}


Table 14

Direct and indirect control of publicly held firms: ten 'medium-size' firms

\begin{tabular}{|c|c|c|c|c|c|c|c|}
\hline & \multirow{2}{*}{$\begin{array}{c}\text { Widely } \\
\text { held }\end{array}$} & \multicolumn{6}{|c|}{ Dominant shareholder } \\
\hline & & Family & $\begin{array}{c}\text { Widely held } \\
\text { non- } \\
\text { financial }\end{array}$ & Foreign & $\begin{array}{c}\text { Govern- } \\
\text { ment }\end{array}$ & $\begin{array}{c}\text { Institutional } \\
\text { investor } \\
\text { or bank }\end{array}$ & Non-profit \\
\hline Austria & 3 & 5 & 0 & 0 & 2 & 0 & 0 \\
\hline Belgium & 1 & 7 & 0 & 0 & 2 & 0 & 0 \\
\hline Canada & 6 & 4 & 0 & 0 & 0 & 0 & 0 \\
\hline Finland & 4 & 3 & 0 & 2 & 1 & 0 & 0 \\
\hline France & 2 & 7 & 0 & 1 & 0 & 0 & 0 \\
\hline Germany & 0 & 7 & 1 & 1 & 0 & 1 & 0 \\
\hline Hong Kong & 3 & 7 & 0 & 0 & 0 & 0 & 0 \\
\hline Ireland & 8 & 1 & 0 & 1 & 0 & 0 & 0 \\
\hline Israel & 3 & 6 & 1 & 0 & 0 & 0 & 0 \\
\hline New Zealand & 5 & 3 & 0 & 2 & 0 & 0 & 0 \\
\hline Norway & 3 & 5 & 0 & 0 & 2 & 0 & 0 \\
\hline Portugal & 0 & 9 & 1 & 0 & 0 & 0 & 0 \\
\hline Singapore & 2 & 5 & 0 & 1 & 2 & 0 & 0 \\
\hline Spain & 3 & 5 & 0 & 2 & 0 & 0 & 0 \\
\hline Sweden & 3 & 7 & 0 & 0 & 0 & 0 & 0 \\
\hline Switzerland & 5 & 3 & 0 & 2 & 0 & 0 & 0 \\
\hline United Kingdom & 6 & 4 & 0 & 0 & 0 & 0 & 0 \\
\hline United States & 6 & 4 & 0 & 0 & 0 & 0 & 0 \\
\hline
\end{tabular}

